\title{
21. PRELIMINARY LIPID ANALYSES OF TWO QUATERNARY SEDIMENTS FROM THE MIDDLE AMERICA TRENCH, SOUTHERN MEXICO TRANSECT, DEEP SEA DRILLING PROJECT LEG 66 ${ }^{1}$
}

\author{
S. C. Brassell, G. Eglinton, and J. R. Maxwell, School of Chemistry, University of Bristol, Bristol, United Kingdom
}

\begin{abstract}
We investigated the solvent-extractable hydrocarbons, ketones, alcohols, and carboxylic acids of two Quaternary sediments from the Middle America Trench (Sections 487-2-3 and 491-1-5). These lipids are derived from a mixed input of autochthonous and allochthonous materials, with minor contributions from thermally mature sources. Their compositions are typical of those of immature Quaternary marine sediments, and their lipid distributions show many similarities to those of Japan Trench sediments.
\end{abstract}

\section{INTRODUCTION}

The solvent-extractable lipids of two Quaternary sediments (Sections 487-2-3 and 491-1-5) from the oceanic plate and central slope of the Middle America Trench were investigated by gas chromatography and computerized gas chromatography-mass spectrometry. The sections were chosen to permit the comparison of environments on either side of the trench. This preliminary report describes the lipid compositions of these two samples and interprets them in terms of their input sources, conditions of deposition, and extent of diagenesis. We also make a brief comparison of their lipid distributions with those of Quaternary sediments from the Japan Trench.

Table 1 summarizes the lithological characteristics of the samples and includes their weights. Organic carbon determinations were not made for these samples, but the values of adjacent sections are given (site chapters, this volume).

\section{EXPERIMENTAL}

The experimental procedures for Leg 66 samples generally follow those of our earlier DSDP investigations (Barnes et al., 1979; Brassell et al., 1980a, 1980b). Gas chromatographic (GC) analyses were performed on a 20m OV-1 WCOT capillary column fitted in a Carlo Erba 2150 instrument. Computerized gas chromatography-mass spectrometry (C-GC-MS) was used to achieve compound identification. The Finnigan 4000 system with INCOS 2300 data system has been described elsewhere (Brassell et al., 1980d), but for these analyses a 20-m fused silica column coated with methyl silicone fluid led through to the ion source was used. Compound assignments were made from individual mass spectra and GC retention times, with reference to literature spectra and authentic standards, where possible. Mass fragmentography (MF) was used extensively to characterize homologous and pseudohomologous series and to aid in compound identification. Individual components were quantitated from their GC response, where possible, from their C-GC-MS response or by MF. For particular compound classes either the small quantities or problems with component coelution prevented absolute quantitation. In such instances, a semiquantitative estimate of their relative abundances is given.

\footnotetext{
1 Initial Reports of the Deep Sea Drilling Project, Volume 66.
}

\section{RESULTS}

The distributions of aliphatic hydrocarbons, ketones, alcohols, and carboxylic acids and of aromatic hydrocarbons are reported herein. In addition, other suites of components such as $\alpha, \omega$-dicarboxylic acids and numerous minor or unrecognized compounds were detected, but are not included.

\section{Aliphatic Hydrocarbons}

\section{Acyclic Components}

The $n$-alkanes of Sections 487-2-3 and 491-1-5 both ranged from $\mathrm{C}_{14}$ to $\mathrm{C}_{35}$ with $n-\mathrm{C}_{29}$ dominant. The concentrations of individual homologues are shown in Figure 1A and the CPI values in Table 2. Both distributions are dominated by the odd-numbered $n$-alkanes in the $C_{25}$ to $C_{35}$ range, but in Section 491-1-5 the $C_{17}$ to $C_{22}$ homologues are also prominent. No $n$-alkenes were detected in either sample. Iso- and anteiso- alkanes in the $\mathrm{C}_{17}$ to $\mathrm{C}_{23}$ range were recognized as minor components ( $<0.5 \mathrm{ng} / \mathrm{g}$ ) of Sections 487-2-3 and 491-1-5. No other simple branched alkanes or alkenes were found in either sediment.

Seven isoprenoid alkanes were found in both samples; the concentrations of five of them, 2,6,10-trimethylpentadecane, pristane $(2,6,10,14$-tetramethylpentadecane), phytane $(2,6,10,14$-tetramethylhexadecane), 2,6,10,15, 19-pentamethyleicosane (I), and squalane $(2,6,10,15,19$, 23-hexamethyltetracosane, II), recognized by comparison with literature spectra (e.g., Holzer et al., 1979), are shown in Figure 1A. For Section 487-2-3 the identification of 2,6,10,15,19-pentamethyleicosane is tentative; the mass spectrum suggested a contribution to the GC peak from another acyclic isoprenoid alkane, perhaps 2,6,10,14,18-pentamethyleicosane (III, Holzer et al., 1979). The presence of the two other acyclic isoprenoid alkanes was suggested by the enhanced response of the $\mathrm{m} / \mathrm{z} 183$ MF (Albaiges, 1980) for the $n-\mathrm{C}_{34}$ and $n-\mathrm{C}_{35}$ peaks in GC-MS. From these mass spectral data the acyclic isoprenoid alkanes coeluting with these $n$-alkanes are probably $2,6,10,14,17,21,25,29$-octamethyl- 
Table 1. Sample descriptions and lithological characteristics.

\begin{tabular}{|c|c|c|c|c|c|c|c|}
\hline \multirow[b]{2}{*}{ Site Location } & \multirow{2}{*}{$\begin{array}{c}\text { Sample } \\
\text { (interval in } \mathrm{cm} \text { ) }\end{array}$} & \multirow{2}{*}{$\begin{array}{l}\text { Sub-bottom } \\
\text { Depth } \\
\text { (m) }\end{array}$} & \multirow[b]{2}{*}{ Age } & \multirow[b]{2}{*}{ Lithology } & \multirow{2}{*}{$\begin{array}{c}\text { Organic } \\
\text { Carbon } \\
(\%)\end{array}$} & \multicolumn{2}{|c|}{ Weight (g) } \\
\hline & & & & & & Wet $^{\mathrm{a}}$ & Dry ${ }^{b}$ \\
\hline oceanic plate & $487-2-3,135-150$ & 5.2 & middle-late Pleistocene & mud & $1.7^{\mathrm{c}}$ & 83 & 47 \\
\hline central trench slope & $491-1-5,110-135$ & 7.2 & Quaternary & muddy silt & $1.9^{\mathrm{d}}$ & 162 & 108 \\
\hline
\end{tabular}

\footnotetext{
a Weight prior to extraction.

$\mathrm{b}$ All lipid concentrations are quoted in $\mathrm{ng} / \mathrm{g}$ dry weight of sediment.

c Value for Section 487-2-2, 40.

d Value for Section 491-1-5, 101
}

hentriacontane (IV) and lycopane $(2,6,10,14,19,23,27$, 31-octamethyldotriacontane, V), since both possess prominent m/z 183 ions (Moldowan and Seifert, 1979; Kimble et al., 1974) and appropriate retention times. Trace concentrations $(<0.7 \mathrm{ng} / \mathrm{g})$ of two phytene isomers with mass spectra similar to that of phyt-2-ene (3, 7, 11, 15- tetramethylhexadec-2-ene, VI; Urbach and Stark, 1975) were found in Section 491-1-5.

\section{Cyclic Components}

A series of cyclohexylalkanes ranging from $\mathrm{C}_{16}$ to $\mathrm{C}_{26}$ was recognized by MF (m/z 83 and 82$)$ in Section 4911-5. The concentration of the major homologue, cyclohexyldodecane (VII), was approximately $0.8 \mathrm{ng} / \mathrm{g}$. These components were not detected in Section 487-2-3.

Fichtelite (VIII) was detected as a minor component (approx. $0.3 \mathrm{ng} / \mathrm{g}$ ) of Section 487-2-3 but was not present in Section 491-1-5. Section 487-2-3 also contained compounds with mass spectra similar to published spectra of a $\mathrm{C}_{25} \mathrm{H}_{44}$ bicyclic alkadiene $\left(\mathrm{M}^{ \pm}+344\right.$, Farrington et al., 1977; Boehm and Quinn, 1978) and a $\mathrm{C}_{30} \mathrm{H}_{52}$ bicyclic alkatriene (M+412, I2558 of Prahl et al., 1980). Of the three major fragment ions in the spectra, two (m/z 231 and $\mathrm{m} / \mathrm{z} 259)$ are common to both components, whereas the third occurs at $68 \mathrm{amu}$ higher $(\mathrm{m} / \mathrm{z}$ 315 rather than $\mathrm{m} / \mathrm{z} 247$ ) in the spectrum of the $C_{30}$ compound, suggesting that the two hydrocarbons share a common bicyclic skeleton and differ by one isoprene $\left(\mathrm{C}_{5} \mathrm{H}_{8}\right)$ unit. The mass spectral data do not, however, permit unambiguous assignment of the structure of these $\mathrm{C}_{25}$ and $\mathrm{C}_{30}$ compounds, which are present in concentrations of $6.5 \mathrm{ng} / \mathrm{g}$ and $4.6 \mathrm{n} / \mathrm{g}$, respectively.

Steranes (IX) and diasteranes (X) were recognized by MF (m/z 217) as minor components of both samples. The distributions of these compounds in the two sediments were similar, but their low concentrations $(<0.5$ $\mathrm{ng} / \mathrm{g}$ and $<0.3 \mathrm{ng} / \mathrm{g}$ for Sections 487-2-3 and 491-1-5, respectively) prevented component identification from individual mass spectra. Hence, an accurate assessment of the maturity of the steranes from specific stereoisomeric ratios (Mackenzie et al., 1980) was not possible, although the apparent proportions of $20 \mathrm{~S}$ - and $14 \beta(\mathrm{H})-$ steranes and diasteranes, as seen from MF, were comparable in both samples with those in petroleums and mature sediments (Seifert and Moldowan, 1979; Mackenzie et al., 1980). Sterenes were significant components of both sections, but the complexity of the polycyclic region of the hydrocarbon fractions prevented their absolute quantitation. In addition, the mass spectral differences between sterenes, steradienes, and stera- trienes preclude their quantitation from a single MF. Hence, Table 3 gives only approximate concentration values derived from the total ion intensities of individual sterene mass spectra. Ster-2-enes (XII) and stera3,5-dienes (XIII) were recognized by comparison with standard spectra; the nuclear positions of unsaturation of the other components are uncertain. Three of the sterenes with nuclear triunsaturation are thought to possess aromatic A or B rings (XIV or XV); Spyckerelle, 1975; Rullkötter et al., in press). Their mass spectral similarities to D ring aromatic hopanes (Greiner et al., 1977) suggest that B ring aromaticity (XV) is the more probable. The distributions and approximate concentrations of sterenes in Sections 487-2-3 and 491-1-5 are generally similar. Section $487-2-3$ appears to contain greater relative amounts of nuclear triunsaturated sterenes, whereas Section 491-1-5 possesses higher abundances of stera-3,5-dienes.

A wide range of triterpenoid hydrocarbons was found in both samples, although as with the sterenes, their absolute quantitation was not possible. The abundances given in Table 4 are therefore approximate values calculated from the total ion signal of individual mass spectra. The intensities for each component's $\mathrm{m} / \mathrm{z} 191$ response, relative to that of the major triterpenoid, are also given. The majority of compounds were recognized from their mass spectra by comparison with those of standards or by MF. Two components with mass spectra and GC retention times similar to those of two of the three unknown triterpenoid hydrocarbons-those assigned as $\mathrm{C}_{30}$ triterpenes in Table 4-were previously found in Section 481-2-2 (Thomson et al., in press b); their structures have not been characterized. The relative abundances of hop-22(29)-ene (diploptene, XVIIIf) and homohop-29(31)-ene (XVIIIi) are markedly higher in Section 487-2-3 than in Section 491-1-5, whereas the latter sample contains a greater abundance of fernenes and $\alpha \beta$-hopanes, notably the $\mathrm{C}_{31}$ to $\mathrm{C}_{35}$ homologues. In other respects the distributions and approximate concentrations of triterpenoid hydrocarbons in the two sediments are generally similar. Neither triterpanes nor triterpenes with 6-membered $\mathrm{E}$ rings, such as gammacerane (XXVI) and olean-18-ene (XXVII), were detected in the samples. Both sections, however, contained a suite of eight $\mathrm{C}_{24}$ components that were tentatively assigned as tetracyclic degradation products of 3-oxytriterpenoids (Fig. 2). The mass spectrum of component D is the same as that of a compound originally found in the Messel shale (Kimble, 1972), which has been characterized as a tetracyclic alkane (XXVIII) related to 
A

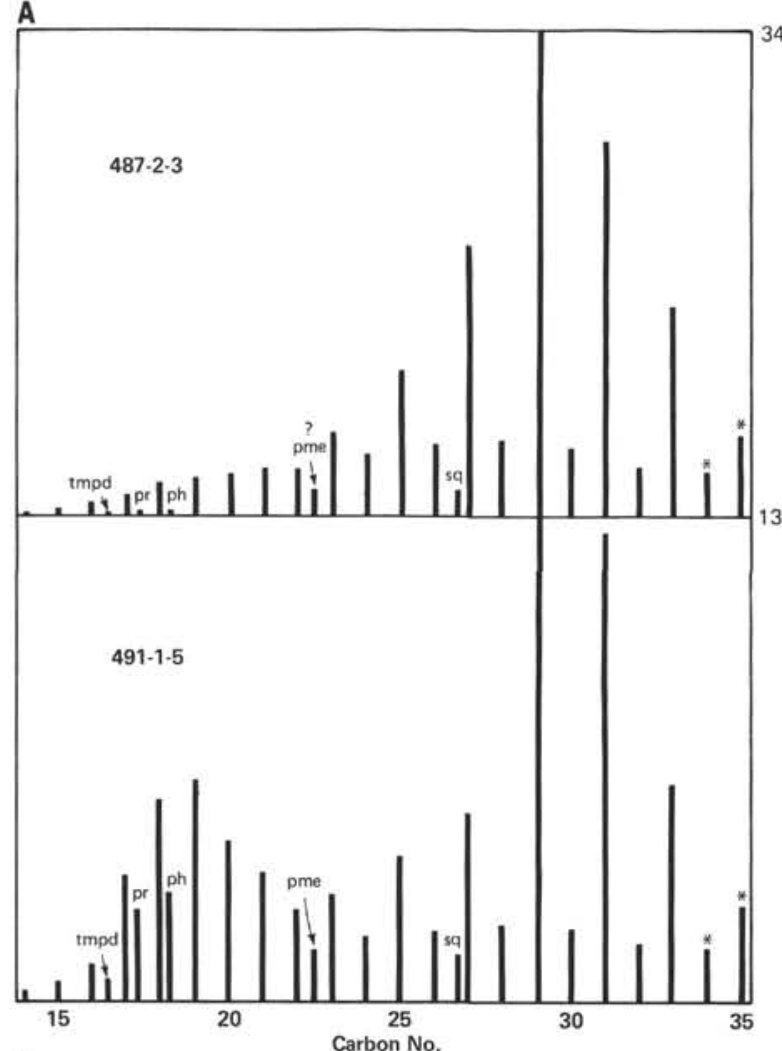

C

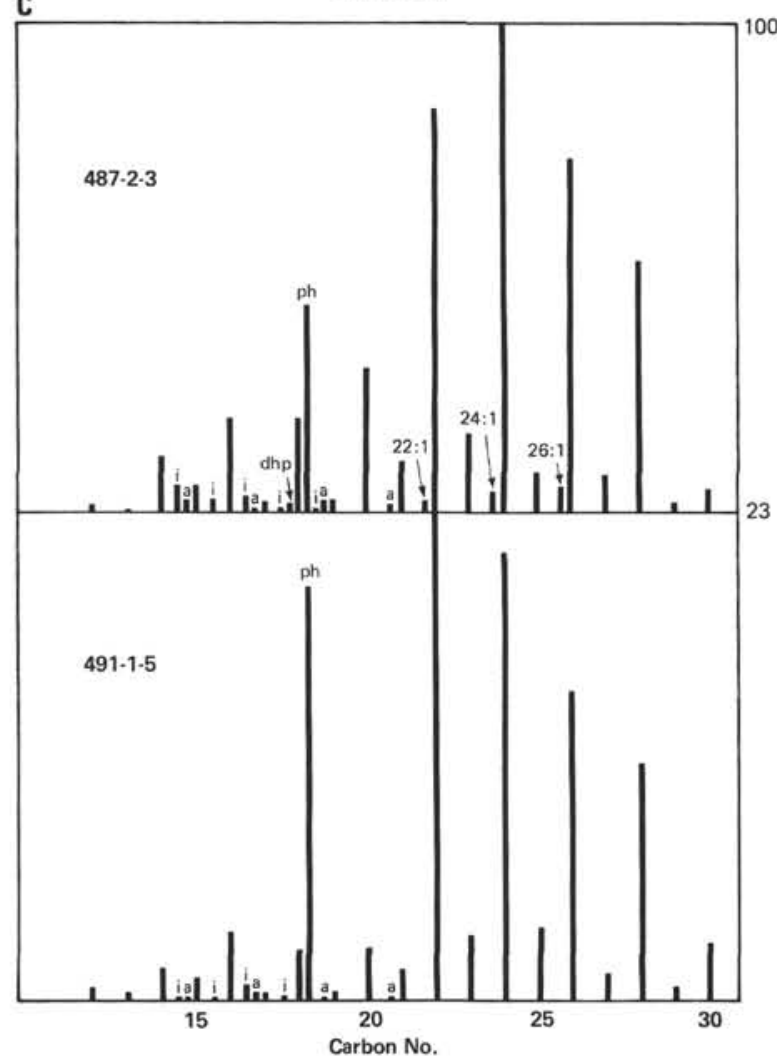

B
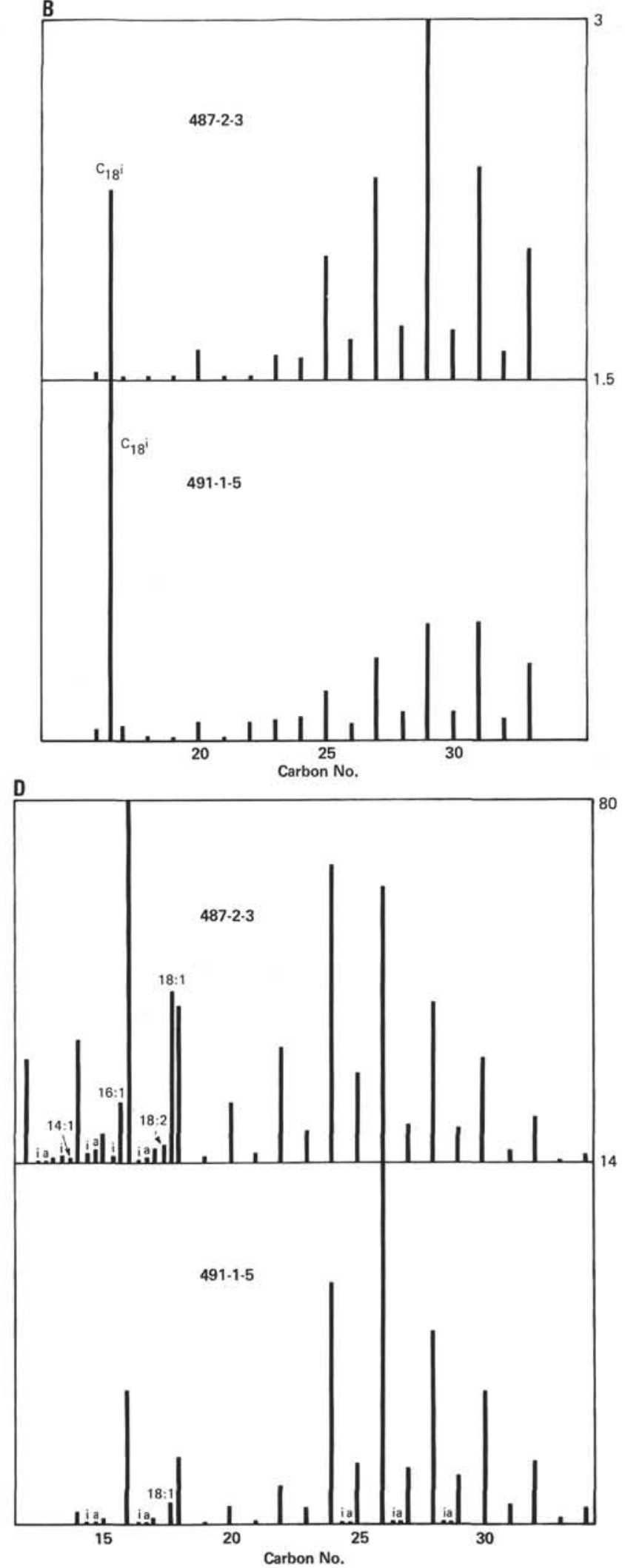

Figure 1. Concentrations (ng/g dry sediment) of acyclic hydrocarbons, ketones, alcohols, and acids in Sections 487-2-3 and 491-1-5. A. $n$-alkanes. (tmpd =2,6,10-trimethylpentadecane; $\mathrm{pr}=$ pristane; $\mathrm{ph}=$ phytane; $\mathrm{pme}=2,6,10,15,19$-pentamethyleicosane; $\mathrm{sq}=$ squalane; * $=n$-alkane peaks enhanced by coelution of acyclic isoprenoid alkanes [see text].) B. $n$-alkan-2-ones. $\left(\mathrm{C}_{18} \mathrm{i}=6,10,14\right.$-trimethylpentadecan-2-one.) C. $n$-alkanols. ( $\mathrm{i}=$ iso-alkanols; $\mathrm{a}=$ anteiso-alkanols; $\mathrm{dhp}=$ dihydrophytol; $\mathrm{ph}=$ phytol; $22: 1,24: 1$, $26: 1=$ alkenols.) D. $n$-alkanoic acids. $(\mathrm{i}=$ iso-alkanoic acids; $\mathrm{a}=$ anteiso-alkanoic acids; $14: 1,16: 1,18: 1,18: 2=$ alkenoic acids.) 
Table 2. Carbon preference indices of normal components in the samples.

\begin{tabular}{|c|c|c|c|c|}
\hline \multirow[b]{2}{*}{ Compound Class } & \multirow[b]{2}{*}{ C No. Range } & \multicolumn{2}{|c|}{ Section } & \multirow{2}{*}{$\begin{array}{l}\text { Odd/Even or } \\
\text { Even/Odda }\end{array}$} \\
\hline & & $487-2-3$ & $491-1-5$ & \\
\hline & $(14-33$ & 3.5 & 2.5 & $\mathrm{o} / \mathrm{e}$ \\
\hline \multirow[t]{2}{*}{$n$-alkanes } & $\{14-21$ & 1.2 & 1.2 & $\mathrm{o} / \mathrm{e}$ \\
\hline & $(22-33$ & 4.1 & 3.7 & o/e \\
\hline$n$-alkan-2-ones & $16-33$ & 4.5 & 2.8 & $\mathrm{o} / \mathrm{e}$ \\
\hline \multirow{2}{*}{$n$-alkanols } & $11-30$ & 5.7 & 7.4 & $e / o$ \\
\hline & $(12-34$ & 6.3 & $5.5^{\mathrm{b}}$ & e/o \\
\hline \multirow[t]{2}{*}{$n$-alkanoic acids } & $\{12-21$ & 11.7 & $12.2^{\mathrm{C}}$ & $e / o$ \\
\hline & $(22-34$ & 4.7 & 4.9 & e/o \\
\hline
\end{tabular}

a Odd/even predominance o/e; even/odd predominance e/o

${ }^{b} \mathrm{CPI}$ for $\mathrm{C}_{14-34}$ range.

c CPI for $\mathrm{C}_{14-21}$ range.

Table 3. Abundance of sterenes in Sections 487-2-3 and 491-1-5.

\begin{tabular}{|c|c|c|c|}
\hline \multirow[b]{2}{*}{ Assignment } & \multirow[b]{2}{*}{ Structure } & \multicolumn{2}{|c|}{$\begin{array}{l}\text { Abundance in } \\
\text { Section }\end{array}$} \\
\hline & & $487-2-3$ & $491-1-5$ \\
\hline cholesta-n,24-diene ${ }^{a}$ & XIb & + & + \\
\hline cholest-2-ene & XIIa & ++ & ++ \\
\hline cholesta-3,5-diene & XIIIa & ++ & ++ \\
\hline 24-methylenecholestene & XId & +++ & ++ \\
\hline 24-methylenecholest-2-ene & XIIc & ++ & + \\
\hline 24-methylenecholestene & XId & $++t$ & $++t$ \\
\hline 24-ethylcholesta-n,22-diene ${ }^{\mathrm{a}}$ & $\mathrm{XIe}\}$ & $+t+$ & +++ \\
\hline 24-methylcholestatriene & XIc & + & ++ \\
\hline 24-methylcholesta-3,5-diene & XIIIc & n.d. & ++ \\
\hline 24-methylcholestatriene & XIc & ++ & + \\
\hline 23,24-dimethylcholest-2-ene & XIIf & + & ++ \\
\hline 24-ethylcholest-2-ene & XIIg & ++ & ++ \\
\hline cholestatriene & $\mathrm{XIVa}$ or $\mathrm{XVa}$ & + & n.d. \\
\hline 24-ethylidenecholestene & XIh & +++ & +++ \\
\hline 24-ethylcholesta-3,5-diene & XIIIe & + & ++ \\
\hline 24-ethyldenecholestadiene & XIh & +++ & ++ \\
\hline 24-methylcholestatetriene & XIVd or XVd & + & + \\
\hline 24-ethylcholestatriene & $\mathrm{XIVg}$ or $\mathrm{XVg}$ & + & n.d. \\
\hline
\end{tabular}

Note: Section 487-2-3: $+++=$ approx. $3 \mathrm{ng} / \mathrm{g} ;++=$ approx. $1.5 \mathrm{ng} / \mathrm{g} ;+=$ approx. $<0.5 \mathrm{ng} / \mathrm{g}$. Section 491-1-5: $+++=$ approx. $3 \mathrm{ng} / \mathrm{g} ;++=1 \mathrm{ng} / \mathrm{g} ;+=<0.3 \mathrm{ng} / \mathrm{g}$. n.d. $=$ not detected.

${ }^{a} \mathrm{n}$ designates nuclear double bond in an uncertain position.

lupane (XXIX, Corbet et al., 1980). The identities of the other components cannot be unambiguously assigned from their mass spectra. The distributions of these compounds in the two samples are similar, but they are present in rather greater concentrations in Section 487-2-3 than in Section 491-1-5.

\section{Aromatic Hydrocarbons}

Aromatic hydrocarbons were minor components of both samples (approx. $\leq 1 \mathrm{ng} / \mathrm{g}$ ), with the exception of perylene (XXXIX) in Section 491-1-5. The small amounts of these compounds prevented their accurate quantitation; hence, Table 5 gives approximate values for their concentrations, estimated from the total ion signal of their mass spectra or from MF of their molecular ions. Simonellite (XXX), retene (XXXI), and perylene (XXXIX) were identified from C-GC-MS by comparison with standard spectra, whereas the tri- and di-
Table 4. Abundance of triterpenoid hydrocarbons in Sections 487-2-3 and 491-1-5.

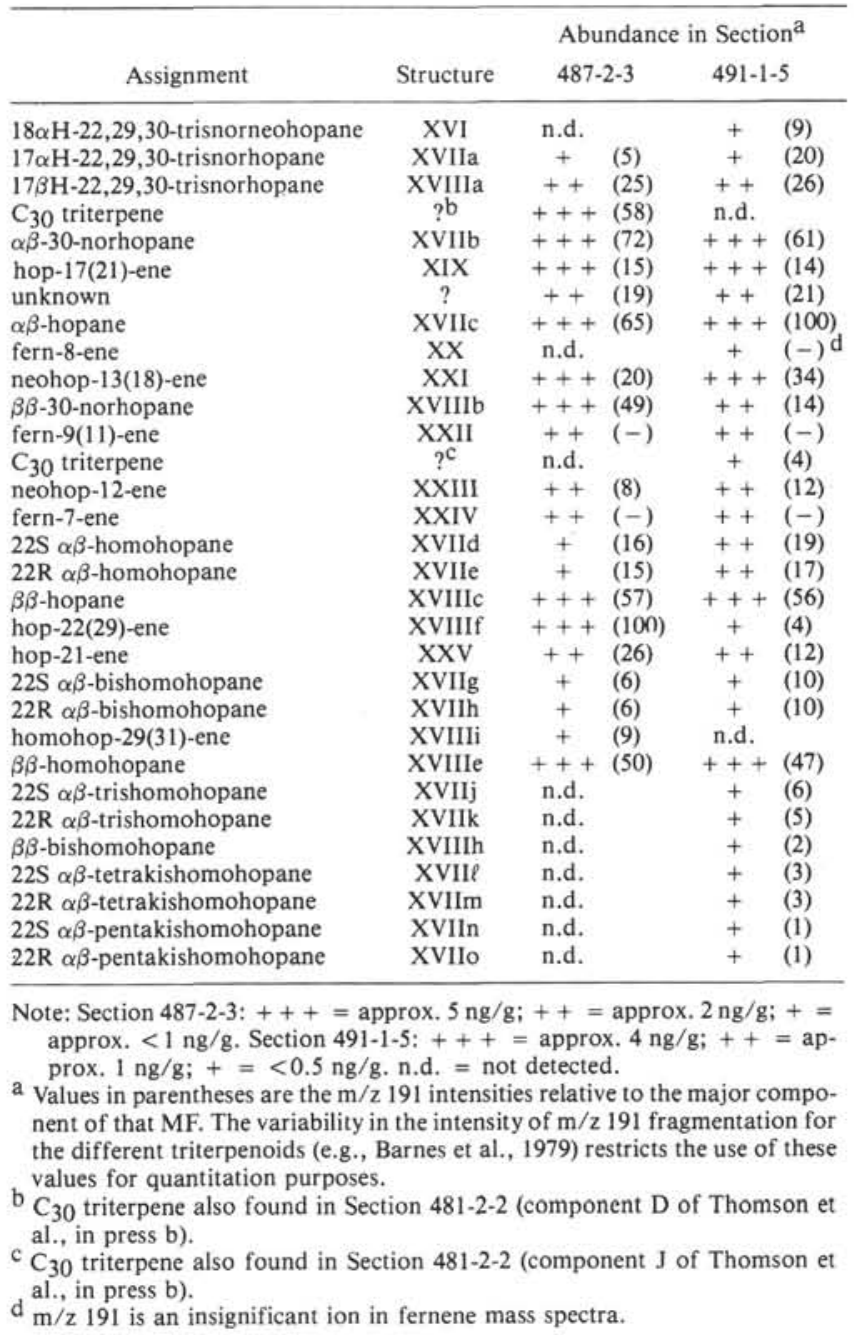

aromatic tetracyclic components (XXXIV to XXXVIII) were recognized by comparison with literature spectra (Spyckerelle, 1975; Spyckerelle et al., 1977a, 1977b; Laflamme and Hites, 1979; Wakeham et al., 1980a, 1980b). Assignments of the monoaromatic tetracyclic components (XXXII and XXXIII) were made by comparison with a literature spectrum (Spyckerelle, 1975) and by spectral interpretation. In addition to the aromatic hydrocarbons listed in Table 5 and the monoaromatic steroids just discussed, series of ring $\mathrm{C}$ aromatic steroids (XL, Schaeffle et al., 1978) were found as trace components $(<0.1 \mathrm{ng} / \mathrm{g})$ of both samples. The major difference between the two distributions of aromatic hydrocarbons, which were present at similar concentrations in both sections, is the greater abundance of the aromatic diterpenoids simonellite and retene in Section 491-1-5.

Ketones

\section{Acyclic Components}

In both samples the $n$-alkan-2-ones are dominated by odd-numbered components as seen in their CPI values 


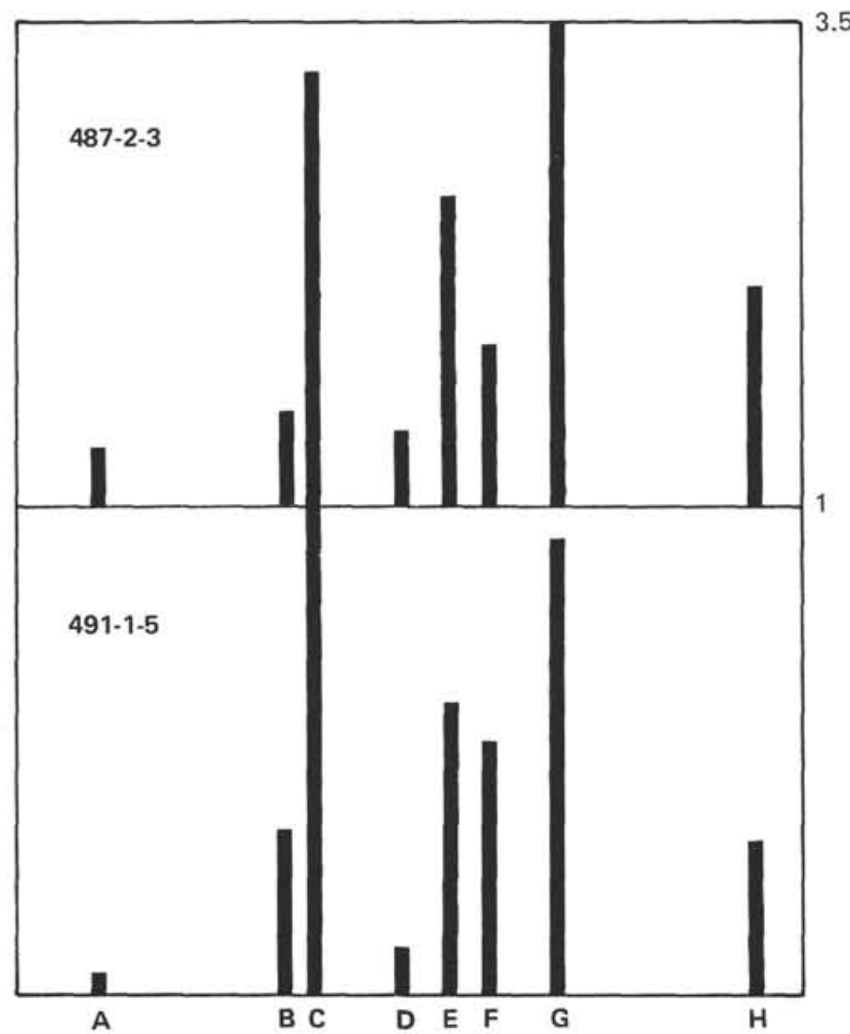

Figure 2. Concentrations (ng/g dry sediment) of $\mathrm{C}_{24}$ tetracyclic alkenes/alkanes, assigned as ring A degraded triterpenoids, in Sections 487-2-3 and 491-1-5. (Formulae: A, B, C, E, F, and $\mathrm{H}=$ $\mathrm{C}_{24} \mathrm{H}_{28}(\mathrm{M} \div 326) ; \mathrm{D}=\mathrm{C}_{24} \mathrm{H}_{32}\left(\mathrm{M} \div 330\right.$, XXVIII); $\mathrm{G}=\mathrm{C}_{24} \mathrm{H}_{30}$ $(M \div 328)$.)

(Table 2). The concentrations of individual members of the homologous series, which range from $\mathrm{C}_{16}$ to $\mathrm{C}_{33}$, are illustrated in Figure 1B. The $\mathrm{C}_{29}$ and $\mathrm{C}_{31}$ components are the dominant homologues of Sections 487-2-3 and 491-1-5, respectively. The two samples contain similar distributions of long-chain unsaturated ketones (Fig. 3) but not the full suite of $\mathrm{C}_{37}$ to $\mathrm{C}_{39}$ compounds found elsewhere (Brassell et al., 1980b; de Leeuw et al., 1980; Volkman et al., 1980a, 1980b). These limited ranges of alkadienones and alkatrienones are dominated by the $\mathrm{C}_{37: 2}$ methyl ketone (heptatriaconta-15,22-diene-2-one, XLIa), which is the major ketone in these sediments. No other alkenones or simple branched acyclic ketones were recognized in either sample. 6,10,14-trimethylpentadecan-2-one was present as a prominent component of both sections (Fig. 1B); indeed, in Section 491-1-5 it is more abundant than the $n$-alkanones. No other acyclic isoprenoid ketone was found in the sections.

\section{Cyclic Components}

The minor components of both samples included steroidal ketones that were identified from standard or literature spectra (Gagosian and Smith, 1979; Withers et al., 1978), by spectral interpretation or from their GC retention times using MF. $5 \alpha$ - and $5 \beta$-cholestan-3-one (XLIIIa and XLIVa), 24-ethyl-5 $\alpha$-cholestan-3-one (XLIIIb), dinosterone $(4 \alpha, 23,24$-trimethyl-5 $\alpha$-cholest22 -en-3-one, XLVc), dinostanone $(4 \alpha, 23,24$-trimethyl$5 \alpha$-cholestan-3-one, XLVd), and an isomer of dinostanone, probably differing in its side chain methylation (perhaps $4 \alpha, 22,24$-trimethyl, XLVe or $4 \alpha, 22,23$-trimethyl, XLVf), were identified in the samples. Dinosterone was the dominant component of both distributions, found in minor amounts $(<0.1 \mathrm{ng} / \mathrm{g})$ and approximately $1 \mathrm{ng} / \mathrm{g}$ in Sections 487-2-3 and 491-1-5, respectively. None of the other steroidal ketones was present in more than trace concentrations $(\ll 0.1 \mathrm{ng} / \mathrm{g})$.

Both samples contain hopanoid and nonhopanoid triterpenones, but their distributions differ significantly (Table 6). 22,29,30-trisnorhopan-21-one (XLVI) and 30norhopan-22-one (L) were assigned by comparison with literature spectra (Dastillung et al., 1980a); recognition of the other triterpenones was made by comparison with standard spectra and from their GC retention times. 22,29,30-trisnorhopan-21-one (XLVI) is the major triterpenone of Section 491-1-5 but was not detected in Section 487-2-3, whereas friedelan-3-one (LIII) was a major component of both sections. Apart from these two compounds, none of the other triterpenones was present at concentrations $>0.2 \mathrm{ng} / \mathrm{g}$. Hence, Table 6 provides estimates of their concentrations calculated from their total ion intensities or from MF.

\section{Alcohols \\ Acyclic Components}

The $n$-alkanols of Sections 487-2-3 and 491-1-5 range from $C_{12}$ to $C_{30}$, with the even-numbered components dominant. Their concentrations are shown in Figure 1C,

Table 5. Abundance of aromatic hydrocarbons in Sections 487-2-3 and 491-1-5.

\begin{tabular}{|c|c|c|c|c|}
\hline \multirow[b]{2}{*}{ Assignment } & \multirow[b]{2}{*}{ Formula } & \multirow[b]{2}{*}{ Structure } & \multicolumn{2}{|c|}{$\begin{array}{l}\text { Abundance in } \\
\text { Section }\end{array}$} \\
\hline & & & $487-2-3$ & $491-1-5$ \\
\hline 1,1-dimethyl-7-isopropyl-1,2,3,4-tetrahydrophenanthrene (simonellite) & $\mathrm{C}_{19} \mathrm{H}_{24}$ & $\mathrm{XXX}$ & n.d. & +++ \\
\hline 1-methyl-7-isopropylphenanthrene (retene) & $\mathrm{C}_{18} \mathrm{H}_{20}$ & $\mathrm{XXXI}$ & + & ++ \\
\hline $3,4,7,10 \mathrm{~b}, 12 \mathrm{a}$-pentamethyl-1, 2,3,4,4a,4b,5,6,10b,11,12,12a-dodecahydrochrysene $\mathrm{a}$ & $\mathrm{C}_{23} \mathrm{H}_{34}$ & XXXII & + & + \\
\hline $3,3,7,10 \mathrm{a}, 12 \mathrm{a}$-pentamethyl-1,2,3,4,4a,4b,5,6,10b,11,12,12a-dodecahydrochrysene & $\mathrm{C}_{23} \mathrm{H}_{34}$ & XXXIII & + & + \\
\hline 2,8-dimethyl-5'-isopropyl-1,2-cyclopentano-1,2,3,4-tetrahydrophenanthrene & $\mathrm{C}_{22} \mathrm{H}_{30}$ & XXXIV & +++ & $++t$ \\
\hline 3,4,7,12a-tetramethyl-1,2,3,4,4a,11,12,12a-octahydrochrysene & $\mathrm{C}_{22} \mathrm{H}_{30}$ & $\mathrm{XXXV}$ & +++ & +++ \\
\hline $3,3,7,12 \mathrm{a}$-tetramethyl-1,2,3,4,4a,11,12,12a-octahydrochrysene & $\mathrm{C}_{22} \mathrm{H}_{30}$ & XXXVI & ++ & ++ \\
\hline 3,4,7-trimethyl-1,2,3,4-tetrahydrochrysene & $\mathrm{C}_{21} \mathrm{H}_{26}$ & XXXVII & + & + \\
\hline 3,3,7-trimethyl-1,2,3,4-tetrahydrochrysene & $\mathrm{C}_{21} \mathrm{H}_{26}$ & XXXVIII & + & ++ \\
\hline perylene & $\mathrm{C}_{20} \mathrm{H}_{12}$ & XXXIX & + & $7 \mathrm{ng} / \mathrm{g}$ \\
\hline
\end{tabular}

Note: Sections 487-2-3 and 491-1-5: $+++=$ approx. $1 \mathrm{ng} / \mathrm{g} ;++=$ approx. $0.2 \mathrm{ng} / \mathrm{g} ;+=<0.1 \mathrm{ng} / \mathrm{g} . \mathrm{n} . \mathrm{d} .=$ not detected.

a Tentative assignment based on spectral interpretation. 


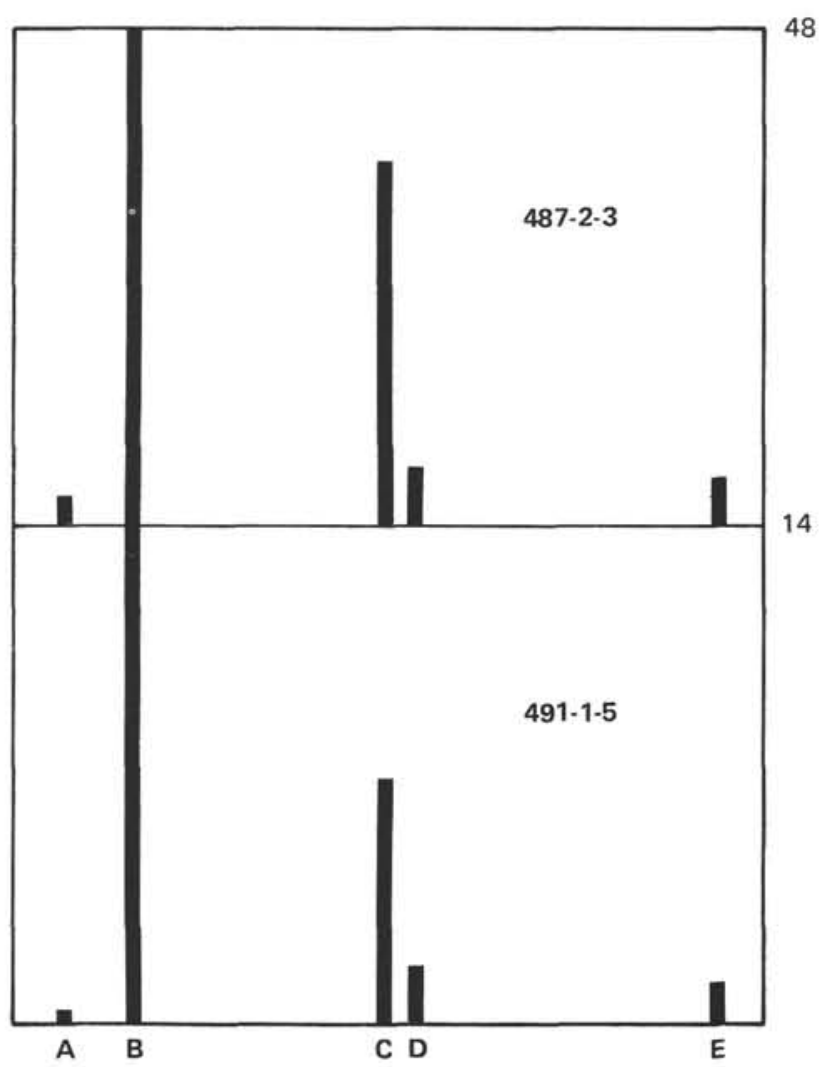

Figure 3. Concentrations (ng/g dry sediment) of alkadienones and alkatrienones in Sections 487-2-3 and 491-1-5. (A = heptatriaconta-8,15-22-trien-2-one (XLa); B = heptatriaconta-15,22-dien2-one (XLIa); C = octatriaconta-16-23-dien-3-one (XLIb); $\mathrm{D}=$ octatriaconta-16,23-dien-2-one (XLIc); $\mathrm{E}=$ nonatriaconta-17,24dien-3-one (XLId).)

Table 6. Abundance of triterpenoid ketones in Sections 487-2-3 and 491-1-5.

\begin{tabular}{lccc}
\hline & & \multicolumn{3}{c}{$\begin{array}{c}\text { Abundance in } \\
\text { Section }\end{array}$} \\
\multicolumn{1}{c}{ Assignment } & Structure & $487-2-3$ & $491-1-5$ \\
\hline 22,29-30-trisnorhopan-21-one & XLVI & n.d. & $8 \mathrm{ng} / \mathrm{g}$ \\
taraxer-14-en-3-one & XLVII & + & + \\
olean-12-en-3-one & XLVIII & + & + \\
urs-12-en-3-one & XLIX & + & + \\
$\begin{array}{l}\text { 30-norhopan-22-oneb } \\
\beta \beta \text {-hopan-3-one }\end{array}$ & L & + & + \\
glut-5-en-3-one & LI & n.d. & + \\
friedelan-3-one & LII & ++ & n.d. \\
\hline
\end{tabular}

Note: Sections 487-2-3 and 491-1-5: $++=0.2 \mathrm{ng} / \mathrm{g} ;+=$ $<0.1 \mathrm{ng} / \mathrm{g}$. n.d. $=$ not detected.

a Stereochemistry of $\mathrm{C}-17$ uncertain (cf. Dastillung et al., 1980a).

b Stereochemistry of C-17 and C-21 uncertain but may be $\beta \alpha$ (cf. Dastillung et al., 1980a).

and Table 2 gives their CPI values. The two distributions are broadly similar, but Section 487-2-3 contains higher relative amounts of short-chain $\left(C_{14}\right.$ to $\left.C_{20}\right)$ members and is dominated by the $\mathrm{C}_{24}$ rather than the $\mathrm{C}_{22}$ alkanol. Section 487-2-3 contained three $n$-alkenols (Fig. 1C), but none was detected in Section 491-1-5. Iso- and anteiso-alkanols ranging from $\mathrm{C}_{15}$ to $\mathrm{C}_{21}$ were found in both samples (Fig. 1C), but no $n$-alkan-2-ols (cf. Cranwell, 1980) were detected. Phytol $(3,7,11,15$ tetramethylhexadec-2-enol) was a prominent component of both samples (Fig. 1C) but dihydrophytol $(3,7$, 11,15 -tetramethylhexadecanol) was only found in Section 487-2-3.

\section{Cyclic Components}

Sterols were major components of both sections; the concentrations of the 35 compounds characterized (Table 7) are shown in Fig. 4. Standard and literature spectra (Gaskell and Eglinton, 1976; Wardroper et al., 1978; Lee et al., 1979; Wardroper, 1979; Boon et al., 1979; Brassell and Eglinton, 1981; Brassell, 1980 and references therein) and GC retention times were used for most sterol identifications; other assignments are based on spectral interpretation (Table 7).

Dinosterol [ $4 \alpha, 23,24$-trimethyl-5 $\alpha$-cholest-22(E)-en$3 \beta-o l$, LVIj] was the dominant sterol of both sections, which possessed similar distributions, except for the greater prominence of $5 \alpha$-stanols and $\mathrm{C}_{29} \Delta^{22}$ components in Section 491-1-5. No sterols with short side chains $\left(<\mathrm{C}_{26}\right)$ were detected (cf. Brassell et al., 1980b; Brassell, 1980).

Both hopanoid and nonhopanoid triterpenols were recognized in the sediments (Table 8), although their distributions (Fig. 5) are somewhat dissimilar. Most

Table 7. Sterols identified in Sections 487-2-3 and 491-1-5.

\begin{tabular}{|c|c|c|}
\hline $\begin{array}{c}\text { Peak } \\
\text { (Fig. 4) }\end{array}$ & Assignment & Structure \\
\hline A & 24-norcholesta-5,22(E)-dien-3 $\beta$-ol & LIVa \\
\hline B & 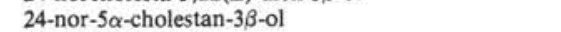 & $\mathrm{LVb}$ \\
\hline $\mathrm{C}$ & 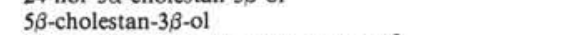 & LXV1 \\
\hline $\mathrm{D}$ & 27 -nor- 24 -methyl- $5 \beta$-cholestan-3 $\beta$-ol ${ }^{\mathrm{a}}$ & LXVII \\
\hline $\mathrm{E}$ & $5 \beta$-cholestan-3 $\alpha$-ol & LXVIII \\
\hline $\mathrm{F}$ & 27-nor-24-methylcholesta-5,22(E)-dien-3 $\beta$-ol & LIVe \\
\hline G & 27 -nor-24-methyl-5 $\alpha$-cholest-22(E)-en-3 $\beta$-ol & LVe \\
\hline $\mathrm{H}$ & cholesta-5,22(E)-dien-3 $\beta$-ol & LIVf \\
\hline 1 & 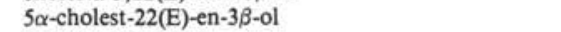 & LVf \\
\hline J & cholest-5-en-3 $\beta$-ol & LIVc \\
\hline $\mathrm{K}$ & $5 \alpha$-cholestan-3 $\beta$-ol & LVc \\
\hline L & 27-nor-24-methyl-5 $\alpha$-cholestan-3 $\beta$-ol & LVd \\
\hline $\bar{M}$ & 24 -methylcholesta-5,22(E)-dien-3 $\beta$-ol & $\mathrm{LIVg}$ \\
\hline $\mathrm{N}$ & 24 -methyl-5 $\alpha$-cholest-22(E)-en-3 $\beta$-ol & $\mathrm{LVg}$ \\
\hline o & 24 -methylenecholest-5-en-3 $\beta$-ol & LIVh \\
\hline & 24-methylene-5 $\alpha$-cholestan-3 $\beta$-ol & $\mathrm{LVh}$ \\
\hline $\mathbf{P}$ & 24-methylcholest-5-en-3 $\beta$-ol & LIVi \\
\hline Q & 24 -methyl-5 $\alpha$-cholestan-3 $\beta$-ol & $\mathrm{LVi}$ \\
\hline $\mathbf{R}$ & 23,24 -dimethylcholesta- 5,22 (E)-dien-3 $\beta$-ol & LIVj \\
\hline & 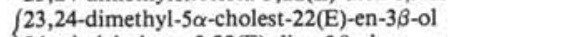 & $\mathrm{LVj}$ \\
\hline $\mathrm{s}$ & $\{24$-ethylcholesta-5,22(E)-dien-3 $\beta$-ol & LIVk \\
\hline \multirow{2}{*}{$\mathrm{T}$} & 24-ethyl-5 $\alpha$-cholest-22(E)-en-3 $\beta$-ol & LVk \\
\hline & 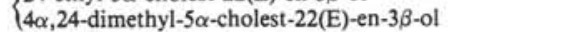 & LVIg \\
\hline \multirow[b]{2}{*}{$\mathrm{U}$} & $\{23,24$-dimethyl- $5 \alpha$-cholestan- $3 \beta$-ol & LVe \\
\hline & 24-ethylcholest-5-en-3 $\beta$-ol & LIVm \\
\hline \multirow[b]{2}{*}{ V } & 24 -ethyl-5 $\alpha$-cholestan-3 $\beta$-ol & LVm \\
\hline & 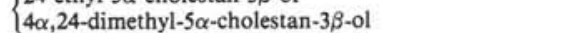 & LVIi \\
\hline w & $24(\mathrm{Z})$-ethylidenecholest-5-en- $3 \beta$-ol & LIVn \\
\hline $\mathrm{x}$ & $4 \alpha, 23,24$-trimethyl-5 $\alpha$-cholest-22(E)-en-3 $\beta$-ol & LVIj \\
\hline $\mathrm{Y}$ & unknown $\mathrm{C}_{30} 5 \alpha$-stanol $\left(\mathrm{M}^{\dagger} \pm \text { of TMS ether } 500\right)^{\mathrm{c}}$ & $?$ \\
\hline $\mathrm{Z}$ & $24(\mathrm{Z})$-propylidenecholest-5-en- $3 \beta$-ol & LIVo \\
\hline $\mathrm{AA}$ & 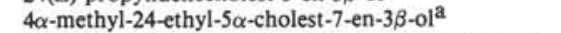 & LVIIm \\
\hline $\mathrm{AB}$ & $4 \alpha, 22,23$ - or $4 \alpha-22,24$-trimethyl- $5 \alpha$-cholestan- $3 \beta$-ol & LVIp or LVIq \\
\hline $\mathrm{AC}$ & 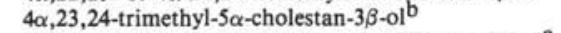 & LVI \\
\hline $\mathrm{AD}$ & 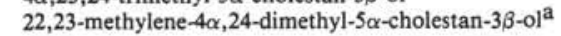 & LVIr \\
\hline
\end{tabular}

a Tentative assignment based on spectra interpretation.

b Compound identified by J. K. Volkman (personal communication).

c Unsaturation is in side chain. 


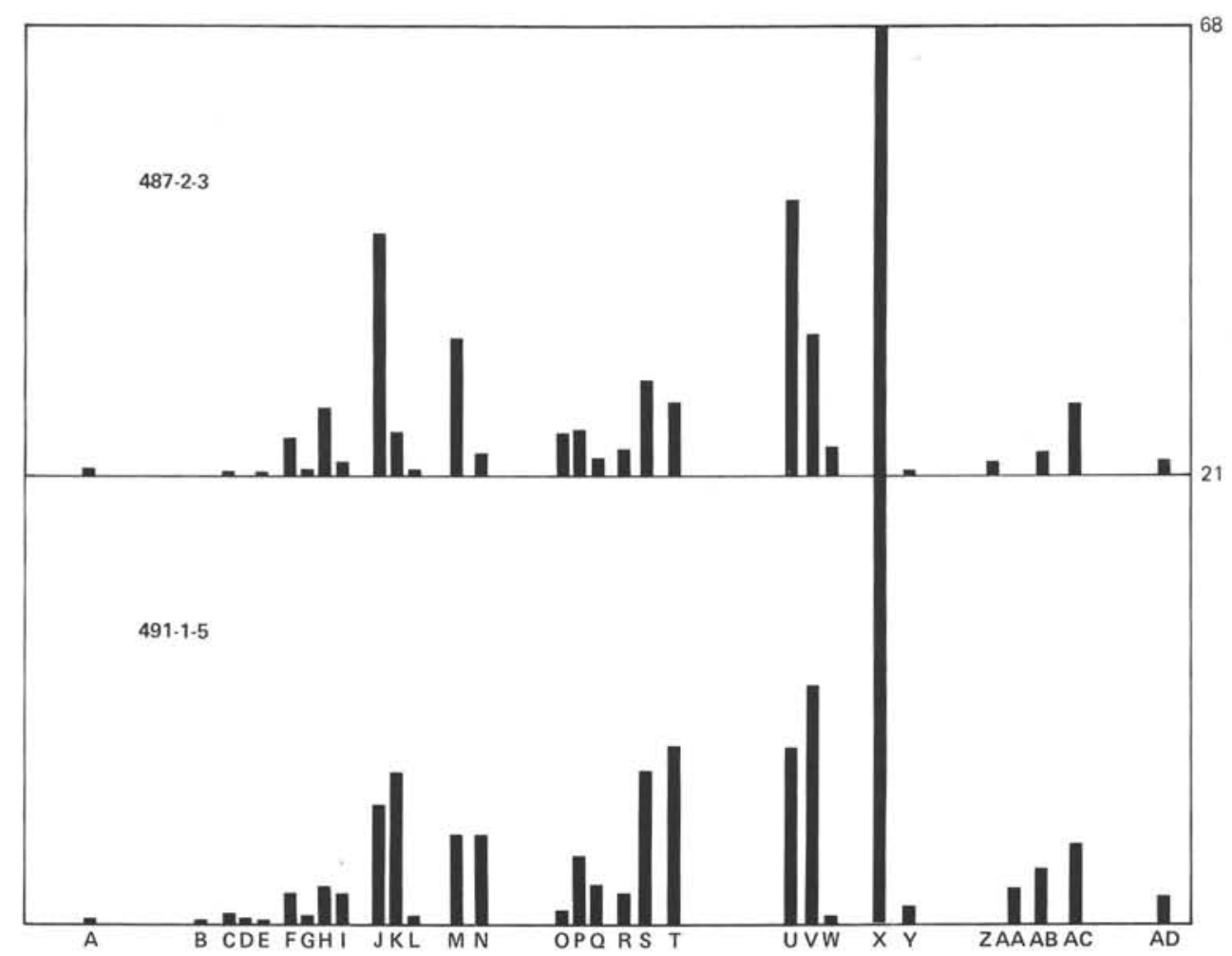

Figure 4. Concentrations (ng/g dry sediment) of sterols in Sections 487-2-3 and 491-1-5. (Assignments are given in Table 7.)

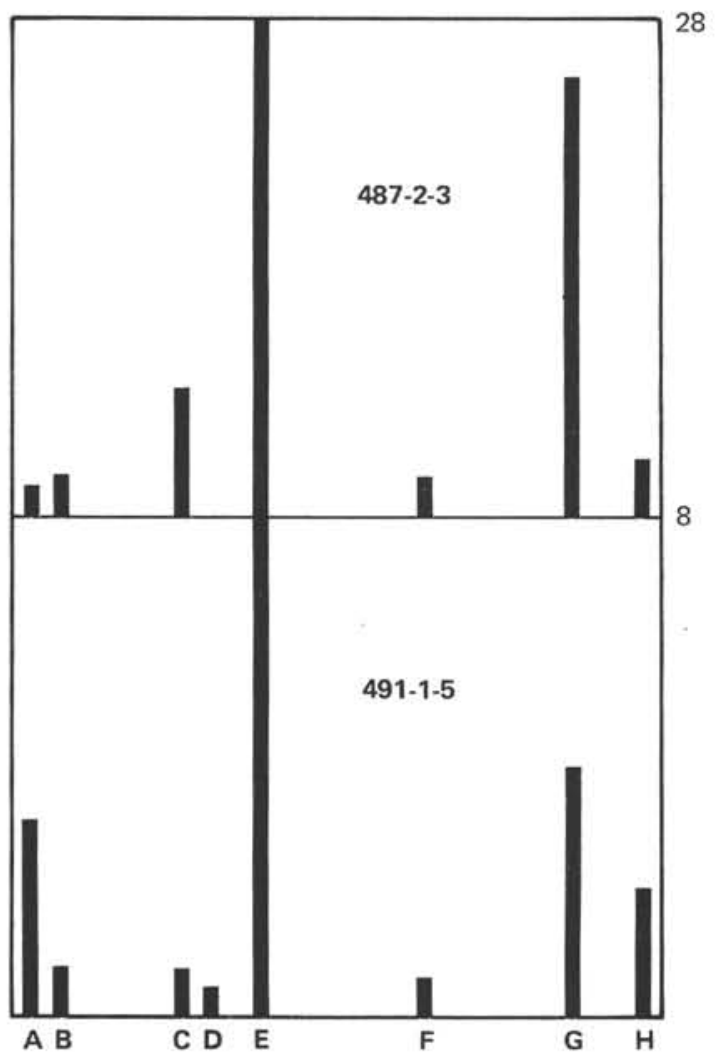

Figure 5. Concentrations (ng/g dry sediment) of triterpenols and hydroxyalkanones in Sections 487-2-3 and 491-1-5. (Assignments are given in Table 8.) components were identified from their mass spectra by comparison with reference standards or literature spectra (Dastillung et al., 1980b) or from MF. The exceptions were taraxer-14-en-3-ol and component D (Table $8)$. Diplopterol ( $\beta \beta$-hopan-22-ol, XVIIIq) was not detected in either sample (cf. Rohmer et al., 1980).

\section{Hydroxyalkanones}

Both samples contained $\mathrm{C}_{30}$ and $\mathrm{C}_{32}$ hydroxyalkanones (LXIIIa and b; Table 8), compounds recently characterized by de Leeuw et al. (personal communication); their concentrations are shown in Fig. 5.

\section{Carboxylic Acids}

\section{Acyclic Components}

The concentrations of $n$-alkanoic acids in Sections 487-2-3 and 491-1-5 are shown in Figure 1D; $C_{16}$ and $C_{26}$ are the major homologues of the respective distributions, which are both dominated by even-numbered components, although they differ markedly in the relative amounts of their short-chain $\left(\mathrm{C}_{12}-\mathrm{C}_{20}\right)$ to longchain $\left(\mathrm{C}_{20}-\mathrm{C}_{34}\right)$ members. In addition to the compounds shown in Figure 1D, Section 487-2-3 contained trace amounts of $\mathrm{C}_{35}$ and $\mathrm{C}_{36} n$-alkanoic acids. $n$-Alkenoic acids were recognized in both samples (Fig. 1D), but a rather greater range of these compounds was present in Section 487-2-3. Iso- and anteiso-alkanoic acids were also found in both samples, but the carbon number ranges varied (Fig. 1D). In particular, $C_{25}, C_{27}$, and $C_{29}$ components were detected only in Section 491-1-5. 


\section{Cyclic and Aromatic Components}

Dehydroabietic acid (LXIV) was detected only in Section 487-2-3 (approx. $0.5 \mathrm{ng} / \mathrm{g}$ ); no other diterpenoid acids and no steroidal acids were found in either sample. $\beta \beta$-bishomohopanoic acid (XVIIIu) was recognized in Sections 487-2-3 and 491-1-5 at concentrations of approximately $1.6 \mathrm{ng} / \mathrm{g}$ and $<0.2 \mathrm{ng} / \mathrm{g}$, respectively. Section 491-1-5 also contained traces of $\beta \beta$-homohopanoic acid (XVIIIv). Nonhopanoid triterpenoid acids, possibly related to amyrin or friedelane skeletons (cf. Corbet et al., 1980), were present in minor amounts in Section 487-2-3, but lack of standard mass spectra precluded their identification.

\section{DISCUSSION}

\section{Lipid Yields}

Although the total lipid yields of Sections 487-2-3 and 491-1-5 have not been determined, the concentrations of individual lipids provide a measure of their total lipid content. The abundances of the compound classes evaluated in the two samples are considerably lower than those of other Quaternary marine sediments analyzed in our laboratory (e.g., Walvis Bay, Wardroper, 1979; Japan Trench, Brassell et al., 1980b, 1980c; California continental borderland, McEvoy et al., in press; Guaymas Basin, Thomson et al., in press b). Such sediments, however, show greater variability in their concentrations of components of marine origin (e.g., sterols and alkenones) than of terrestrial origin (e.g., $n$-alkanes in all the samples except Walvis Bay). The lower abundances of marine components relative to terrestrial components in the Middle America trench samples compared with the other sediments may therefore, in part, reflect less intensive water column productivity, although other environmental conditions are undoubtedly also important.

\section{Paleoenvironmental Assessment: Lipid Indicators}

\section{Straight-Chain Components}

The distributions of saturated straight-chain components ( $n$-alkanes, $n$-alkan-2-ones, $n$-alkanols, and $n$-alkanoic acids) are consistent with a mixed input from autochthonous and allochthonous sources. The $n$-alkane distributions maximizing at $n$ - $\mathrm{C}_{29}$ (Fig. 1A), with a prominent odd/even preference in the $C_{22}$ to $C_{33}$ range (Table 2), are similar to those of higher plant waxes (e.g., Eglinton et al., 1962) and suggest that the $n$-alkanes reflect terrigenous input (e.g., Simoneit, 1978; Brassell et al., 1978). Evidence of major autochthonous input is not reflected by the lower $n$-alkanes, especially $n-\mathrm{C}_{17}$. The mediety of $n-\mathrm{C}_{17}$ may, however, be due to its preferential biodegradation relative to higher $n$-alkanes (e.g., Johnson and Calder, 1973; Brassell et al., 1978) in both water column and sediment rather than to a low level of algal productivity in the euphotic zone. In addition, that higher plants possess greater concentrations of $n$-alkanes in their surface waxes than do algae makes $n$-alkanes more sensitive indicators of terrestrial than of phytoplankton inputs. The short-chain $n$-alkanes of both samples possess similar low CPI values (Table 2), but these compounds are present in greater concentrations in Section 491-1-5 than Section 487-2-3, in contrast to the overall abundance of $n$-alkanes in the two samples. In view of the evidence for thermally mature inputs to the samples (see the following) it seems probable that the short-chain $n$-alkanes of Section 491-1-5 are, at least in part, derived from such a source.

The $n$-alkan-2-one distributions resemble those of the $n$-alkanes, especially in Section 487-2-3 (cf. Fig. 1A and B). Such similarity suggests that the $n$-alkan-2-ones originate from alkane oxidation rather than from $\beta$-oxidation of alkanoic acids (Brassell et al., 1980c and references therein), but it is unclear whether such oxidation occurs at a pre- or postdepositional stage. In Section 491-1-5 the low relative abundance of short-chain $n$-alkan-2-ones, in contrast to the $n$-alkane distributions, suggests predepositional alkane oxidation.

Two possible sources of the $n$-alkanols and $n$-alkenols in marine sediments are input from the wax esters of marine organisms or lipid contributions from terrigenous higher plants. In higher plant waxes hexacosanol is the dominant homologue (Eglinton and Hamilton, 1967), whereas zooplankton wax esters contain $C_{16}$ to $C_{22}$ alkanol moieties (Benson and Lee, 1975), although their composition varies with growth conditions (Lee et al., 1971). The distributions of $n$-alkanols in Sections 487-2-3 and 491-1-5 do not therefore correspond well with an origin from either source. Indeed, similar distributions have been interpreted as both wax ester (Ikan et al., 1975) and terrestrial input (Aizenshtat et al., 1973; Brassell et al., 1980c). The presence of $C_{22}$ to $C_{26}$ $n$-alkenols in Section 487-2-3 further confuses the issue in that $C_{20: 1}$ and $C_{22: 1}$ are the major alkenoid moieties of calanoid copepods (Nevenzel, 1970) and higher plants are not known to contain these compounds. These discrepancies between the biological and sedimentary distributions of $n$-alkanols and $n$-alkenols precludes the unambiguous assignment of their biological origin.

The distributions of $n$-alkanoic and $n$-alkenoic acids suggest input from both autochthonous and allochthonous sources. The prominence of $C_{22}$ to $C_{34} n$-alkanoic acids with even/odd predominance (Table 2 ) is consistent with input from terrigenous plants (e.g., Simoneit, 1978). The widespread occurrence of $C_{16}$ and $C_{18} n$-alkanoic acids in biota makes them nondiagnostic source indicators, whereas the relative abundance of $\mathrm{C}_{12}$ and $\mathrm{C}_{14} n$-alkanoic acids in Section 487-2-3 suggests autochthonous lipid inputs. It is not possible, however, to differentiate between algal and bacterial autochthonous input of carboxylic acids without information regarding the geometrical isomerism of the $n$-alkenoic acids (Volkman and Johns, 1977). The shorter-chain $n$-alkanoic and $n$-alkenoic acids might also originate from marine wax esters (Boon and de Leeuw, 1979).

The only organism in which the $\mathrm{C}_{37}$ to $\mathrm{C}_{39}$ alkenones (XLI, XLII) have been recognized is Emiliania huxleyi (Volkman et al., 1980a, 1980b). Hence, these ketones have been ascribed to coccolithophore input to sediments, even where deposition below the CCD has de- 
stroyed any skeletal evidence of such organisms (Brassell et al., 1980b, 1980c; Volkman et al., 1980a). A major difference between the distribution of alkenones in Sections 487-2-3 and 491-1-5 and in E. huxleyi is the ratio of di- to triunsaturated homologues. In E. huxleyi the alkatrienones are dominant, although analysis at the motile, sessile, and coccolith stages of growth shows that the ratio of alkadienones to alkatrienones varies throughout the growth cycle (Volkman et al., 1980a). In contrast, the alkenone distributions of sediments are generally dominated by the alkadienones (di/tri ratios range from 0.7 to 4; Volkman et al., 1980a; Brassell et al., 1980b), but Sections 487-2-3 and 491-1-5 possess alkadienones/alkatrienones ratios an order of magnitude higher (33 and 57 , respectively). This dissimilarity in the alkenone ratios may reflect sediment contributions from $E$. huxleyi that has grown under different environmental conditions or an input from an organism that biosynthesises these alkenones with a different alkadienone/alkatrienone ratio. Alternatively, the alkatrienones may be more easily degraded relative to the alkadienones in the Middle America Trench than in other sediments.

Although the biological source of the hydroxyalkanones (LXIII) is uncertain because they have yet to be recognized in organisms, they are probably of marine origin in view of their geological occurrence (de Leeuw, personal communication; Thomson et al., in press, b). The absence of the $\mathrm{C}_{31}$ hydroxyalkanone is not unexpected, since this component is present in markedly lower concentrations than the $\mathrm{C}_{30}$ and $\mathrm{C}_{32}$ homologues in other sediments (de Leeuw et al., personal communication; Thomson et al., in press b).

\section{Branched-Chain Components}

Short-chain iso- and anteiso-alkanoic acids are constituents of bacteria (e.g., Parker et al., 1967; Cranwell, 1973), hence the occurrence of such $C_{13}$ to $C_{17}$ components (Fig. 1D) in Sections 487-2-3 and 491-1-5 may be attributed to input from bacteria (e.g., Simoneit, 1978; Brassell et al., 1980c). By analogy, the iso- and anteiso-alkanols $\left(\mathrm{C}_{15}-\mathrm{C}_{21}\right.$, Fig. $\left.1 \mathrm{C}\right)$ are also of bacterial origin (Brassell et al., 1980c). In contrast, the $\mathrm{C}_{25}, \mathrm{C}_{27}$, and $\mathrm{C}_{29}$ iso- and anteiso-alkanoic acids are probably derived from terrestrial sources in view of their relationship to the long-chain 2-and 3-methylalkanes found in higher plant waxes (Eglinton et al., 1962). The iso- and anteiso-alkanes recognized in Sections 487-2-3 and 491-1-5 are short-chain homologues, however, which may be of direct bacterial origin (e.g., from methanogens; Holzer et al., 1979). Alternatively, the widespread occurrence of such compounds in ancient sediments and petroleums (e.g., Tissot and Welte, 1978) suggests that they could be contributed by an input of thermally mature lipids-e.g., from an oil seep or other reworked source. The uniformity of the carbon number distributions of the branched alkanes in Sections 487-2-3 and 491-1-5 differs from the limited range found in bacteria (Holzer et al., 1979) and in sediments thought to reflect bacterial inputs (Brassell et al., 1981) but is consistent with a thermally mature source, which therefore seems the most probable origin of these compounds.

\section{Acyclic Isoprenoid Components}

Despite the nonspecificity of its biological occurrence, the lability of phytol means that its abundance in Sections 487-2-3 and 491-1-5 probably reflects autochthonous marine inputs (Brassell et al., 1980c). In contrast, 6,10,14-trimethylpentadecan-2-one is less readily degraded and may derive from allochthonous sources and/or be generated from phytol within the water column or sediment. There are two possible biological sources for 2,6,10-trimethylpentadecane, pristane, phytane, the phytenes, and dihydrophytol: they may be degradation products of plant phytol and/or inputs from methanogenic sources (e.g., Holzer et al., 1979). In the absence of stereochemical analyses (e.g., Patience et al., 1978) the three alkanes might alternatively originate from mature allochthonous sources (see the following). The recognition of 2,6,10,15,19-pentamethyleicosane (I) and squalane (II) in the samples provides evidence for methanogenic biological activity (Brassell et al., 1980c, 1981). Methanogens may also be the source of lycopane (V), although this compound has yet to be recognized among their lipids (Brassell et al., 1980 c, 1981). Similarly, the acyclic isoprenoids coeluting with 2,6,10,15,19-pentamethyleicosane and $n-\mathrm{C}_{34}$, tentatively assigned as 2,6,10,14,18-pentamethyleicosane (III) and 2,6,10,14,17,21,25,29-octamethylhentriacontane (IV), respectively, are probably of methanogenic origin.

\section{Nonisoprenoidal Cyclic Components}

Alkylcyclohexanes have yet to be found in organisms, although $\omega$-cyclohexylalkanoic acids (LXV) have been recognized as lipid constituents of thermoacidophilic bacteria (e.g., De Rosa et al., 1972). Their occurrence in ancient sediments and petroleums (Johns et al., 1966; Speers and Whitehead, 1969) and their formation in simulated maturation experiments (Ishiwatari and Fukushima, 1979; Rubinstein and Strausz, 1979) suggest that their presence in Section 491-1-5 reflects input from thermally mature sources.

\section{Cyclic Diterpenoid Components}

The four cyclic diterpenoids (fichtelite, simonellite, retene, and dehydroabietic acid; VIII, XXX, XXXI and LXIV) recognized in the sediments are all believed to be diagenetic products of abietic acid (Maxwell et al., 1971; Laflamme and Hites, 1978) and markers for terrigenous input of resinous plants (Simoneit, 1977).

\section{$\mathrm{C}_{25}$ and $\mathrm{C}_{30}$ Unknown Alkenes}

The biological origins of the $\mathrm{C}_{25} \mathrm{H}_{44}$ bicyclic alkadiene and the $\mathrm{C}_{30} \mathrm{H}_{52}$ bicyclic alkatriene are uncertain. The mass spectral, and hence structural, similarities of the two compounds imply that they derive from a common source, which appears to be marine rather than ter- 
restrial. Indeed, a planktonic source for the $\mathrm{C}_{30}$ component has been suggested (Prahl et al., 1980) but has yet to be confirmed by its isolation from such an organism.

\section{Steroidal Components}

The majority of the stenols of Sections 487-2-3 and 491-1-5-namely $\mathrm{C}_{26} \Delta^{5,22}$ and $\mathrm{C}_{27}-\mathrm{C}_{29} \Delta^{5}, \Delta^{5,22}$, and $\Delta^{5,24(28)}$ components $\left(\mathrm{A}, \mathrm{F}, \mathrm{H}, \mathrm{J}, \mathrm{M}, \mathrm{O}, \mathrm{P}_{2}, \mathrm{R}, \mathrm{S}_{2}, \mathrm{U}_{2}\right.$, and $\mathrm{W}$ in Table 7)-may be attributed to phytoplankton inputs (e.g., Boutry and Jacques, 1970; Boutry and Barbier, 1974; Orcutt and Patterson, 1975; Ballantine et al., 1979; Volkman et al., 1980c), although they are not uniquely biosynthesized by these organisms. For example, all of these $\Delta^{5}$-sterols occur in tunicata (Ballantine et al., 1977), but previous investigations of sedimentary sterol distributions (e.g., Lee et al., 1977, 1979; Wardroper et al., 1978; Wardroper, 1979; Brassell, 1980) have ascribed them to phytoplankton or terrestrial higher plant contributions (Huang and Meinschein, 1976).

In Sections 487-2-3 and 491-1-5, as in Japan Trench sediments (Brassell, 1980; Brassell and Eglinton, 1981), the inconsistency of the $\Delta^{5}$-stenol/5 $\alpha$-stanol ratios and the occurrence of only $\mathrm{C}_{27} 5 \beta$-stanols argue against diagenetic reduction of $\Delta^{5}$-stenols (Gaskell and Eglinton, 1975 ) as a major source of $5 \alpha$-stanols. Hence, the $5 \alpha$ stanols probably originate from direct biological inputs to the sediment. $5 \alpha$-Stanols are minor constituents of various organisms, including phytoplankton, zooplankton, and higher plants (e.g., Nishimura and Koyama, 1976, 1977); echinoderms (Goad et al., 1972); coelenterates (Kanazawa et al., 1977); and sponges (Nes and McKean, 1977), which all might contribute lipids to the sediments. These Leg 66 sediments, like most others (cf. Wardroper et al., 1978), contain larger amounts of $5 \alpha$-stanols relative to $\Delta^{5}$-stenols than do organisms, a fact which may largely reflect a bias in the analyses of biological sterols. In particular, stanols can be more prevalent at stationary growth phases than at exponential growth stages (Ballantine et al., 1979). The relative abundance of sedimentary stanols compared with stenols may therefore reflect direct lipid contributions from phytoplankton at their stationary rather than exponential growth stages. Alternatively, $\Delta^{5}$-stenols may be preferentially degraded relative to $5 \alpha$-stanols in the water column, but evidence for the Black Sea shows that this is not the case there (Gagosian et al., 1979).

The overall distribution of 4-desmethyl sterols and stanols suggests that they are largely of phytoplanktonic origin, with the exception of components $\mathrm{U}_{2}$ and $\mathrm{V}_{1}$ (24-ethylcholest-5-en-3 $\beta$-ol, LIVm and 24-ethyl-5 $\alpha$ cholestan-3 $\beta$-ol, LVm; Table 7 and Fig. 4), which may derive from allochthonous inputs of higher plants (Huang and Meinschein, 1976). The absence of $C_{21}$ to $\mathrm{C}_{25}$ stanols and other characteristic sponge and coelenterate sterols (e.g., gorgosterol, LIVs; Wardroper et al., 1978) argues against major lipid inputs from such organisms (cf. Brassell, 1980; Brassell and Eglinton, 1981).

The dominant sterol of both samples is dinosterol (component $\mathrm{X}$ in Table 7 and Fig. 4, LVIj), which is the principal sterol of dinoflagellates (Shimizu et al., 1976) and a marker for dinoflagellate blooms (Boon et al., 1979). Other sedimentary 4-methylstanols may also derive from dinoflagellates (e.g., Withers et al., 1978, 1979), although methanotrophic bacteria contain such compounds and have been suggested as their source (Dastillung et al., 1980b). On present evidence, however, sediment inputs from these two types of organism cannot be distinguished, except that the abundance of dinosterol in sediment traps in the equatorial Atlantic Ocean (Wakeham et al., 1980c) indicates that it can originate from a pelagic source.

The stanones appear to represent direct biological inputs to the sediment, although they are not widely reported as constituents of organisms, with the exception of dinosterone $(4 \alpha, 23,24$-trimethyl-5 $\alpha$-cholest-22-en3-one, XLVc), a known component of dinoflagellates (Withers et al., 1978). The other $4 \alpha$-methylstanones appear to be the 3-oxy equivalents of sterols $\mathrm{AB}$ and dinostanol (AC, LVI $\ell$ ), and may therefore be derived from the same unknown sources. The overall dissimilarity of the sterol and sterone distributions seems to preclude a diagenetic origin for the latter (cf. Gagosian and Smith, 1979; Edmunds et al., 1980).

Sterenes have not been detected among the lipids of any organisms and are regarded as microbial degradation products of sterols (e.g., Dastillung and Albrecht, 1977; Gagosian and Farrington, 1978). In Sections 4872-3 and 491-1-5 the distribution and relative abundances of the sterenes do not parallel those of their presumed precursor sterols, suggesting that their formation is selective, affecting only specific individual sterols or sources of sterols. In particular, the prominence of $\Delta^{24}$-sterenes is disproportionate to the relative abundance of $\Delta^{24}$-stenols and stanols, suggesting that $\Delta^{24}$. sterols may be more susceptible to microbial dehydration than other sterols, such as $\Delta^{22}$ components. Indeed the abundance and range of $\Delta^{22}$-sterols in the sediments (Table 7 and Fig. 4) are markedly greater than those of $\Delta^{22}$-sterenes (Table 3). Among the nuclear unsaturated sterenes, $\Delta^{2}$-sterenes (XII) and $\Delta^{3,5}$-steradienes (XIII) may originate from dehydration of stanols and $\Delta^{5}$. stenols, respectively (e.g., Dastillung and Albrecht, 1977; Gagosian and Farrington, 1978). The recognition of such sterenes in particle traps illustrates their relatively fast formation associated with sinking particles Wakeham et al., 1980c) and attests to their pelagic origin. The source of the steratrienes, thought to be monoaromatic steroids (XIV or XV), is uncertain, but they are probably microbial degradation products of sterols (Gagosian and Farrington, 1978), perhaps stera-5,7dienols (LXIX) which are rarely found intact in sediments (Brassell, 1980; Edmunds et al., 1980).

The absence of 4-methylsterenes in Sections 487-2-3 and 491-1-5, despite the abundance of 4-methylstanols, is consistent with results for other Quaternary marine sediments (Wardroper, 1979; Brassell, 1980; Gagosian et al., 1980; Thomson et al., in press b). It appears, therefore, that defunctionalization of 4-methylstan-3 $\beta$ ols may be inhibited by the steric hindrance of a 4methyl substituent. Such discrepancy in the occurrence of sterenes and 4-methylsterenes compared to 4-des- 
methyl- and 4-methylsterols suggests that microorganisms effect sterol to sterene conversions, since a geochemical transformation would be expected to be less dependent on sterol C-4 substitution (Thomson et al., in press b; Gagosian et al., 1980).

The steranes (IX) and diasteranes (X) of Sections 487-2-3 and 491-1-5 do not represent direct biological input but derive from an allochthonous thermally mature source (see the following).

\section{Triterpenoidal Components}

\section{Hopanoids}

The majority of hopanoids in the two samples are either direct bacterial inputs or diagenetic derivatives of bacterial lipids such as polyhydroxybacteriohopanes (XVIIIw or x, De Rosa et al., 1971; Ourisson et al., 1979; Dastillung et al., 1980a, 1980b; Rohmer et al., 1980). In particular, extended hopanols and hopanoic acids have not been found in organisms; their occurrence in sediments is attributed to oxidation of polyhydroxybacteriohopanes, which are the only extended hopanoids found in biota (Ourisson et al., 1979). Hop17(21)-ene (XIX) and neohop-13(18)-ene (XXI) have been assigned as isomerization products of hop-22(29)ene (XVIIIf) in the Paris Basin (Ensminger, 1977) and as direct terrigenous inputs from ferns in immature sediments from the Japan Trench (Brassell et al., 1980c). The recent recognition of hop-17(21)-ene and neohop(18)-ene in an anaerobic photosynthetic bacterium (Howard, 1980) suggests that these compounds may represent direct sediment inputs of bacterial lipids (Brassell et al., 1981). By analogy, neohop-12-ene (XXIII) may also be derived from bacteria (Brassell et al., 1981) rather than from ferns (Brassell et al., 1980c and references therein). The $\mathrm{C}_{27}$ and $\mathrm{C}_{29}$ hopanoid ketones (XLVI and L), like $n$-alkan-2-ones, may be products of microbial oxidation of the corresponding hydrocarbons (Dastillung et al., 1980a), further illustrating the importance of bacteria in influencing sedimentary lipid compositions.

\section{Nonhopanoids}

Until recently the occurrence of fernenes (XX, XXII, $\mathrm{XXIV)}$ in a sediment was thought to reflect terrestrial inputs, since these triterpenes had only been recognized in ferns (Wardroper, 1979; Brassell et al., 1980c). The discovery of fernenes in a bacterium (Howard, 1980), however, casts doubt on this interpretation and suggests that they may be of microbial origin (Brassell et al., 1981). The other nonhopanoid triterpenones (Table 6) and triterpenols (Table 8 ) are all components of higher plants (e.g., Devon and Scott, 1972) and may therefore represent terrigenous inputs to the samples (Brassell et al., 1980c). Similarly, the tetracyclic aliphatic and aromatic hydrocarbons recognized in Sections 487-2-3 and 491-1-5 (Fig. 2 and Table 5) are of allochthonous, terrigenous origin because they appear to be photochemical or microbially induced photomimetic products of higher plant triterpenoids (Corbet et al., 1980).

The unknown triterpenes found in Sections 487-2-3 and 491-1-5 are of uncertain origin, but a bacterial
Table 8. Triterpenols and hydroxyalkanones identified in Sections $487-2-3$ and $491-1-5$.

\begin{tabular}{|c|c|c|}
\hline $\begin{array}{l}\text { Peak } \\
\text { (Fig. 5) }\end{array}$ & Assignment & Structure \\
\hline A & taraxer-14-en-3-ol ${ }^{\mathrm{a}}$ & LVIII \\
\hline B. & olean-12-en-3-ol ( $\beta$-amyrin) & LIX \\
\hline$-b$ & urs-12-en-3-ol ( $\alpha$-amyrin) & LX \\
\hline $\mathrm{C}$ & $\beta \beta$-hopan-29-ol & XVIIIp \\
\hline $\mathrm{D}$ & 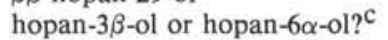 & LXI or LXII? \\
\hline E & hydroxytriacontan-15-one & LXIIIa \\
\hline F & $\beta \beta$-homohopan-31-ol & XVIIIr \\
\hline G & hydroxydotriacontan-15-one & LXIIIb \\
\hline $\mathrm{H}_{3}$ & $\beta \beta$-bishomohopan-32-ol & XVIIIs \\
\hline - b & $\beta \beta$-trishomohopan-33-ol & XVIIIt \\
\hline
\end{tabular}

a Assignment based on spectral interpretation by comparison with spectrum of taraxer-14-en-3-one (XLVII).

$\mathrm{b}$ Compounds present in minor amounts $(<1 \mathrm{ng} / \mathrm{g}$ for Section $487-2-3,<0.3 \mathrm{ng} / \mathrm{g}$ for Section 491-1-5).

c Tentative assignments suggested by mass spectral comparison with standard and literature spectra (Rohmer, 1975), respectively.

source appears probable in view of the fact that the other triterpenes are all attributed to bacterial lipid inputs.

\section{Perylene}

The origin of perylene is uncertain (Wakeham et al., 1979, 1980a), but it appears to be an early-stage diagenetic product formed in situ from unknown precursors. The source of such precursors, i.e. whether marine or terrestrial, is also unclear (Wakeham et al., 1979, 1980a).

\section{Summary}

The lipid markers in the sediments provide evidence for inputs of organic matter from both autochthonous and allochthonous sources (Table 9). The autochthonous indicators include components characteristic of algae and bacteria and of bacterial reworking within the water column or sediment. The lipids of allochthonous origin include compounds derived from higher plants and inputs from a thermally mature source. The lack of full quantitative data for all compounds complicates the assessment of the relative size of autochthonous and allochthonous lipid inputs. On balance, however, the dominance of higher straight-chain compounds derived from terrestrial sources suggests that the major lipid input to both samples is of terrigenous origin, assuming that the $C_{22}$ to $C_{26} n$-alkanols are derived from higher plants. The lipid contributions from algae are of a similar order of magnitude, greatly outweighing the bacterial and thermally mature allochthonous inputs. There are, however, significant differences between Sections 487-2-3 and 491-1-5 in the relative sizes of their four major sources of lipids (Table 9).

\section{Diagenetic Assessment}

The dominant lipids of both sediments are functionalized compounds, namely alcohols, ketones, and carboxylic acids; for example, sterols are markedly more abundant than other steroidal lipids. Such dis- 
Table 9. Lipid markers in Sections 487-2-3 and 491-1-5 indicative of autochthonous and allochthonous sources of organic matter.

\begin{tabular}{|c|c|c|c|c|}
\hline \multirow{2}{*}{$\begin{array}{l}\text { Compound } \\
\text { Structural Class }\end{array}$} & \multicolumn{2}{|c|}{ Autochthonous } & \multicolumn{2}{|c|}{ Allochthonous } \\
\hline & Marine (nonbacterial) & Bacterial $^{\mathrm{a}}$ & Terrestrial (higher plant) & Rederived (thermally mature) \\
\hline (i) straight-chain & $\begin{array}{l}n \text {-alkanols? } \\
n \text {-alkenones: } \\
\text { hydroxyalkanones }\end{array}$ & $\begin{array}{l}\text { Ikenoic acids } \\
\text { ( } n \text {-alkan-2-ones) }\end{array}$ & $\begin{array}{l}n \text {-alkanes; } \\
n \text {-alkan-2-ones; } \\
n \text {-alkanols?; } \\
n \text {-alkanoic acids }\end{array}$ & $n$-alkanes \\
\hline (ii) branched-chain & & $\begin{array}{l}\text { iso- and anteiso- } \\
\text { alkanols and alkanoic acids }\end{array}$ & & $\begin{array}{l}\text { iso- and anteiso- } \\
\text { alkanes }\end{array}$ \\
\hline (iv) nonisoprenoidal cyclics & & & & alkylcyclohexanes \\
\hline (v) cyclic diterpenoids & & & $\begin{array}{l}\text { fichtelite, simonellite, } \\
\text { retene, and } \\
\text { dehydro } \\
\text { abietic acid }\end{array}$ & \\
\hline (vi) unknown alkenes & $\mathrm{C}_{25} \mathrm{H}_{44}$ a & $\mathrm{C}_{30} \mathrm{H}_{52}$ components & & \\
\hline (vii) steroids & $\begin{array}{l}\text { many sterols and } \\
\text { 4-methylstanols; } \\
\text { stanones and } \\
\text { 4-methylstanones }\end{array}$ & (sterenes) & 24-ethylcholesteroids & steranes and diasteranes \\
\hline b) nonhopanoids & & $\begin{array}{l}\text { fernenes? } \\
\text { (tetracyclic aliphatic and } \\
\text { aromatic hydrocarbons) }\end{array}$ & $\begin{array}{l}\text { fernenes? } \\
\text { triterpenones and } \\
\text { triterpenols; tetracyclic } \\
\text { aliphatic and aromatic } \\
\text { hydrocarbons }\end{array}$ & \\
\hline (ix) perylene & ? & ? & ? & \\
\hline
\end{tabular}

${ }^{\text {a }}$ Components in parentheses are assigned as products of bacterial reworking rather than direct input of bacterial lipids.

tributions are characteristic of immature sediments in which diagenetic processes, other than microbial degradation, have not occurred to a marked extent. The lipid analysis of two shallow samples from different sites precludes an evaluation of diagenetic trends in the Middle America Trench, but the extent of microbial degradation of lipids and other early-stage transformations can be assessed.

The presence of diunsaturated carboxylic acids in Section 487-2-3 is an indication of sample immaturity, as such compounds usually undergo rapid microbial breakdown in sediments (e.g., Matsuda and Koyama, 1977). The occurrence of alkenes varies among compound classes: several sterenes derived from sterol precursors were present in both samples, whereas phytenes formed from dehydration of phytol or contributed as direct input from methanogens (Tornabene et al., 1979; Holzer et al., 1979) were only recognized as trace components in Section 491-1-5. No $n$-alkenes were detected. These differences in the occurrence of alkenes suggest that alcohol dehydration is a microbially mediated process rather than a physicochemical reaction in this instance. Sedimentary ketones can come from direct contributions of biological lipids (e.g., sterones) or be derived from the oxidation of input of alkanes, acids, or alcohols (e.g., hopanones). In some instances (e.g., nalkan-2-ones) these two different modes of origin cannot be distinguished on the basis of compound distributions. Overall, the ketones recognized in Sections 487 2-3 and 491-1-5 suggests that their in situ formation by microbial degradation is not a significant process, as illustrated by the disparity of hopanone and other hopanoid distributions.
Hop-22(29)-ene (XVIIIf) originates from a direct autochthonous input and undergoes diagenetic isomerization to hop-21-ene (XXV) and thence to hop-17(21)ene (XIX; Ensminger, 1977; Brassell et al., 1980c). The presence of hop-22(29)-ene and hop-21-ene in the samples is an indication of their immaturity, since these compounds disappear at an early stage of diagenesis (Brassell et al., 1980c). On the basis of their hop-22(29)ene/hop-21-ene ratios, Section 491-1-5 appears to be more mature than Section 487-2-3, but differences in the clay content of the sediment or other lithological characteristics may also influence their rates of isomerization. In addition, the recent recognition of hop-17(21)ene and neohop-13(18)-ene (XXI) in a bacterium (Howard, 1980) means that hop-21-ene may in fact originate as both a direct biological input and an isomerization product of hop-22(29)-ene. Although both samples contained ster-2-enes (XII), no $\Delta^{4}$ - or $\Delta^{5}$-sterenes nor diasterenes were detected, indicating that no isomerization of sterenes has yet occurred (cf. Rubinstein et al., 1975; Wardroper, 1979; Brassell, 1980).

Aromatization, presumably microbial, of diterpenoids, steroids, and triterpenoids can occur at an early stage of diagenesis or, especialy for compounds derived from allochthonous sources, prior to sediment deposition. Whether the aromatic diterpenoids (simonellite, $\mathrm{XXX}$ and retene, XXXI) and the aromatic tetracyclic components derived from nonhopanoid triterpenoids (XXXII-XXXVIII) are formed in situ or predepositionally cannot be resolved from the analysis of an individual shallow sediment. The aromatization of such compounds may be a continuing process in the sediments, however, in view of the presence of incompletely aro- 
matized components (e.g., dehydroabietic acid, LXIV). The presumed precursor of one of the major tetracyclic aromatic components (XXXIV) and the $\mathrm{C}_{24} \mathrm{H}_{32}$ alkane (XXVIII), lupan-3-one (LXVI), was not detected in either sample, suggesting that the microbial degradation of its A ring and subsequent saturation or aromatization (Corbet et al., 1980) is well advanced. In contrast, the minor amounts of steratrienes with aromatic A or B rings (XIV or XV) found in the samples (Table 3 ) suggest that their formation by microbial dehydrogenation or dehydroxylation (e.g., Gagosian and Farrington, 1978) may not be favored in these sediments or that it has not yet proceeded far. The aromatic hopanoids thought to be products of microbial action on other hopanoids (Greiner et al., 1977; Ourisson et al., 1979) were not detected in the samples, although they have been recognized in other marine sediments (e.g., Tissier and Dastillung, 1978). These results may reflect differences in sedimentary microbial populations or overall sample immaturity, since few of the microbial degradation products of lipids are present in any abundance.

The majority of lipids in the sections therefore represent direct biological inputs or microbial degradation products of such inputs (e.g., sterenes). The exceptions are those compounds (steranes, $\alpha \beta$-hopanes, etc.) derived from thermally mature sources whose recognition in shallow, immature DSDP sediments necessitates an evaluation of the possibility of shipboard core contamination from drilling lubricants, principally pipe dope (Brassell and Eglinton, 1980; Thomson et al., in press a). There are, however, significant differences between the thermally mature components of Sections 487-2-3 and 491-1-5 and the hydrocarbons of pipe dope sampled during Leg 59 (Brassell and Eglinton, 1980). These dissimilarities include the distributions of $n$-alkanes, alkylcyclohexanes, extended diterpanes (which are absent in Leg 66 samples), and steranes and the $C_{\max }$ unresolved complex mixture of hydrocarbons. They suggest that pipe dope is not the source of the thermally mature lipids in Sections 487-2-3 and 491-1-5, although the uniformity of its composition cannot be guaranteed. Hence these allochthonous lipids appear to represent a natural, rather than contaminant, input of reworked material, perhaps derived from oil seeps. On the evidence of the distribution of $n$-alkanes assigned as a thermally mature input in Section 491-1-5 it appears that the input is of relatively unbiodegraded material.

\section{Sample Comparisons}

A summary of the qualitative differences and similarities between the lipid compositions of Sections 487-2-3 and 491-1-5 is given in Table 10. In quantitative terms, the lipid content of Section 487-2-3 is generally higher than that of Section 491-1-5 (Table 11); a difference that is probably a function of sediment inputs or of lipid preservation, as seen in Table 10. The larger amounts of autochthonous lipids in Section 487-2-3 may reflect the magnitude of such input and/or their better preservation. The discrepancy in the apparent size of input of bacterial lipids (e.g., branched alkanoic acids) to the samples suggests that their microbial populations may differ, although it may also simply reflect lipid preservation. The few compounds present in greater amounts in Section 491-1-5 than in Section 487-2-3 include those components that are derived largely from thermally mature sources (e.g., $n$-heptadecane in 491-1-5) and certain aromatic components (e.g., retene) and several ketones (e.g., 22,29,30-trisnorhopan-21-one) thought to derive from allochthonous sources. The greater relative proportion of lipids derived from thermally mature sources in Section 491-1-5 may reflect its proximity to such sources. Similarly, consideration of the geographical location of the two sites suggests that the trench slope sample (Section 491-1-5) should possess a higher proportion of lipids of terrestrial origin, which it does in terms of their relative abundance, although their absolute concentration is often lower in Section 491-1-5 than in Section 487-2-3.

The lithological characteristics of the samples may also bear on the relative size of their lipid input from autochthonous and allochthonous sources, since higher plant material may be concentrated in coarser-grained sediment fractions (Thompson and Eglinton, 1978).

\section{Comparison with Japan Trench Samples}

Although a detailed comparison of the lipids of Sections 487-2-3 and 491-1-5 with those of Pleistocene sediment from the Japan Trench (Brassell et al., 1980b, 1980c; Brassell, 1980) is not presented here, the considerable similarity that exists between some of their lipid distributions is illustrated in Figure 6. In addition, Table 12 provides a general comparison between these sediments in terms of the distributions of specific lipid classes. Both suites of samples contain similar series of lipids derived from autochthonous (algal and bacterial) and allochthonous (higher plant) sources, although inevitably there are minor differences in their distributions (Table 12). The more significant discrepancies between the lipid distributions appear to reflect the variety of biological input represented (e.g., sterol distributions are more complex in Japan Trench sediments), the extent of diagenesis (e.g., diasterenes occur only in Japan Trench sediments), the presence or absence of hydrocarbons from thermally mature sources (e.g., branched alkanes in the Middle America Trench sediments), and, possibly, environmental conditions (e.g., alkenone distributions). It is significant, however, that the differences in lipid composition between Sections 487-2-3 and 491-1-5 are as great (or as small) as those between Leg 66 and $56 / 57$ samples.

The resemblance between the lipid distributions of the Middle America and Japan Trench sediments probably reflects a general similarity in their autochthonous and allochthonous lipid input, their conditions of deposition (especially their microbial populations), and their diagenetic processes. The greater relative size of the autochthonous inputs in the Japan Trench sediment (Brassell et al., 1980b, 1980c) is probably a function of water column productivity. 
Table 10. Qualitative differences and similarities between the lipid compositions of Section 487-2-3 and 491-1-5.

\begin{tabular}{|c|c|c|}
\hline Lipid Class & $\begin{array}{l}\text { Comparison between Sections } \\
487-2-3 \text { and } 491-1-5\end{array}$ & Comments \\
\hline \multicolumn{3}{|l|}{ Straight-Chain } \\
\hline$n$-alkanes & $\begin{array}{l}\text { The proportion of short-chain } \\
\text { components is greater in } 491-1-5 \text { (Fig. 1A) }\end{array}$ & $\begin{array}{l}\text { difference arises from thermally mature } \\
\text { inputs in } 491-1-5\end{array}$ \\
\hline$n$-alkan-2-ones & similar (Fig. 1B) & - \\
\hline$n$-alkanols & similar (Fig. IC) & - \\
\hline$n$-alkanoic acids & $\begin{array}{l}\text { short-chain components are more } \\
\text { prominent in } 487-2-3 \text { (Fig. ID) }\end{array}$ & larger autochthonous inputs in $487-2-3$ \\
\hline alkenones & similar (Fig. 3) & - \\
\hline alkenols & detected only in $487-2-3$ (Fig. 1C) & better lipid preservation in $487-2-3$ ? \\
\hline alkenoic acids & $\begin{array}{l}\text { greater range present and more abundant } \\
\text { in } 487-2-3 \text { (Fig. 1D) }\end{array}$ & $\begin{array}{l}\text { autochthonous input larger and better } \\
\text { preserved in } 487-2-3 \text { ? }\end{array}$ \\
\hline hydroxyalkanones & similar (Fig. 5) & - \\
\hline \multicolumn{3}{|l|}{ Branched-Chain } \\
\hline alkanes & more prominent in $491-1-5$ than $487-2-3$ & $\begin{array}{l}\text { occurrence reflects thermally mature } \\
\text { inputs }\end{array}$ \\
\hline alkanols & similar (Fig, 1C) & - \\
\hline alkanoic acids & $\begin{array}{l}\text { short-chain homologues are more } \\
\text { abundant in } 487-2-3 \text {, higher homologues } \\
\text { were found only in } 491-1-5\end{array}$ & $\begin{array}{l}\text { differences reflect greater autoch- } \\
\text { thonous and terrigenous inputs, } \\
\text { respectively }\end{array}$ \\
\hline \multicolumn{3}{|l|}{ Acyclic Isoprenoids } \\
\hline alkanes & $\begin{array}{l}\text { similar, except for the coeluting } C_{25} \\
\text { component in } 487-2-3 \text { (Fig. 1A) }\end{array}$ & $\begin{array}{l}\text { differences may reflect variations in } \\
\text { methanogen populations }\end{array}$ \\
\hline ketone & $\begin{array}{l}6,10,14 \text {-trimethylpentadecan-2-one is } \\
\text { relatively more abundant in } 491-1-5 \\
\text { (Fig. 1B) }\end{array}$ & $\begin{array}{l}\text { greater allochthonous input to or poor } \\
\text { lipid preservation in } 491-1-5 \text { ? }\end{array}$ \\
\hline alcohols & $\begin{array}{l}\text { similar, except that dihydrophytol was } \\
\text { recognized only in } 487-2-3 \text { (Fig. IC) }\end{array}$ & autochthonous inputs may differ \\
\hline \multicolumn{3}{|l|}{ Nonisoprenoid Cyclics } \\
\hline alkylcyclohexanes & detected only in $491-1-5$ & $\begin{array}{l}\text { components originate from thermally } \\
\text { mature input }\end{array}$ \\
\hline \multicolumn{3}{|l|}{ Cyclic Diterpenoids } \\
\hline alkane & fichtelite was detected only in $487-2-3$ & $\begin{array}{l}\text { feature of differences in allochthonous } \\
\text { lipid input or lipid preservation? }\end{array}$ \\
\hline $\begin{array}{l}\text { aromatic } \\
\text { hydrocarbons }\end{array}$ & $\begin{array}{l}\text { simonellite and retene are more abundant } \\
\text { in } 491-1-5\end{array}$ & greater allochthonous input in $491-1-5$ \\
\hline & $\begin{array}{l}\text { dehydroabietic acid was recognized only } \\
\text { in } 487-2-3\end{array}$ & $\begin{array}{l}\text { better preservation of unaltered lipids } \\
\text { in } 487-2-3\end{array}$ \\
\hline \multicolumn{3}{|l|}{ Unknown Cyclics } \\
\hline alkenes & $\begin{array}{l}\mathrm{C}_{25} \mathrm{H}_{44} \text { and } \mathrm{C}_{30} \mathrm{H}_{52} \text { components were } \\
\text { observed only in } 487-2-3\end{array}$ & $\begin{array}{l}\text { autochthonous inputs more prominent } \\
\text { in } 487-2-3\end{array}$ \\
\hline \multicolumn{3}{|l|}{ Steroids } \\
\hline alkanes & $\begin{array}{l}\text { distributions differ in the relative size of } \\
\text { their } \mathrm{C}_{29} \text { components and diasteranes }\end{array}$ & $\begin{array}{l}\text { components derive from separate input } \\
\text { of thermally mature lipids to } \\
\text { each sample }\end{array}$ \\
\hline alkenes & $\begin{array}{l}\text { similar distributions except steratrienes } \\
\text { and stera-3,5-dienes are more abundant in } \\
487-2-3 \text { and } 491-1-5 \text {, respectively (Table 3) }\end{array}$ & $\begin{array}{l}\text { sterenes may originate from different } \\
\text { sources or reflect variability } \\
\text { in diagenesis. }\end{array}$ \\
\hline ketones & similar & - \\
\hline alcohols & $\begin{array}{l}\text { similar, but } 5 \alpha \text {-stanols and } C_{29} \Delta^{22} \\
\text { components are more prominent in } \\
491-1-5 \text { (Fig. } 4 \text { ) }\end{array}$ & sources of sterols differ, in part \\
\hline \multicolumn{3}{|l|}{ Hopanoid Triterpenoids } \\
\hline alkanes & $\begin{array}{l}\text { 491-1-5 contains a higher abundance of } \\
\alpha \beta \text {-hopanes, distributions are otherwise } \\
\text { similar (Table 4) }\end{array}$ & $\begin{array}{l}\text { thermally mature inputs are greater in } \\
491-1-5\end{array}$ \\
\hline alkenes & $\begin{array}{l}\text { similar, except for the prominence of } \\
\text { hop-22(29)-ene in } 487-2-3 \text { (Table 4) }\end{array}$ & $\begin{array}{l}\text { autochthonous input or bacterial } \\
\text { populations differ, or lipids of } 491-1-5 \\
\text { are diagenetically more mature }\end{array}$ \\
\hline ketones & $\begin{array}{l}\text { dissimilar; } 22,29,30 \text {-trisnorhop-21-one, the } \\
\text { major component of } 491-1-5 \text { was not } \\
\text { detected in } 487-2-3 \text { (Table } 6 \text { ) }\end{array}$ & $\begin{array}{l}\text { greater allochthonous input to, or } \\
\text { poorer lipid preservation in, } 491-1-5 ?\end{array}$ \\
\hline alcohols & $\begin{array}{l}\text { similar, except for the absence of } \\
\text { component } D \text { in } 487-2-3 \text { (Fig. 5) }\end{array}$ & $\begin{array}{l}\text { minor differences in autochthonous } \\
\text { inputs }\end{array}$ \\
\hline acids & similar & - \\
\hline \multicolumn{3}{|c|}{$\begin{array}{l}\text { Nonhopanoid Triterpenoids } \\
\text { and Derivatives }\end{array}$} \\
\hline alkanes/alkenes & $\begin{array}{l}\text { fernenes are more prominent in } 491-1-5 \\
\text { tetracyclic alkanes and alkenes are } \\
\text { similar (Fig. 2) }\end{array}$ & $\begin{array}{l}\text { greater allochthonous inputs to } \\
491-1-5 \text {, or different bacterial } \\
\text { populations }\end{array}$ \\
\hline aromatic hydrocarbons & similar (Table 5) & - \\
\hline & $\begin{array}{l}\text { similar, except for the presence of } \\
\text { glutenone in } 487-2-3 \text { (Table } 6 \text { ) }\end{array}$ & $\begin{array}{l}\text { reflects differences in lipid inputs or } \\
\text { preservation? }\end{array}$ \\
\hline alcohols & $\begin{array}{l}\text { taraxerol is more prominent in } 491-1-5 \\
\text { (Fig. 5) }\end{array}$ & $\begin{array}{l}\text { reflects differences in lipid inputs or } \\
\text { preservation? }\end{array}$ \\
\hline \multicolumn{3}{|l|}{ Other } \\
\hline perylene & $\begin{array}{l}\text { perylene is much more abundant in } \\
491-1-5\end{array}$ & $\begin{array}{l}\text { In } 491-1-5 \text { perylene precursors are } \\
\text { more abundant or depositional } \\
\text { conditions are more favorable for } \\
\text { perylene formation }\end{array}$ \\
\hline
\end{tabular}


Table 11. Quantitative comparisons of lipid compositions of Sections 487-2-3 and 491-1-5.

\begin{tabular}{|c|c|c|c|}
\hline \multirow[b]{2}{*}{ Compound (structure) } & \multicolumn{2}{|c|}{$\begin{array}{l}\text { Concentrations }(\mathrm{ng} / \mathrm{g})^{\mathrm{a}} \\
\text { Section }\end{array}$} & \multirow{2}{*}{$\begin{array}{l}487-2-3 / 491-1-5 \\
\text { Ratio }\end{array}$} \\
\hline & $487 \cdot 2 \cdot 3$ & $491-1-5$ & \\
\hline$n$-heptadecane & 1.5 & 3 & 0.5 \\
\hline$n$-nonacosane & 3.4 & 13 & 2.6 \\
\hline$n$-nonacosan-2-one & 3 & 0.5 & 6 \\
\hline n-tetradecanol & 100 & 21 & 4.8 \\
\hline$n$-hexadecanoic acid & 80 & 5.2 & 15 \\
\hline$n$-hexacosanoic acid & 61 & 14 & 4.4 \\
\hline heptatriaconta-15,22-dien-2-one (XLla) & 48 & 14 & 3.4 \\
\hline hydroxytriacontan-15-one (LXIIla) & 28 & 8 & 3.5 \\
\hline 13-methyltetradecanoic acid (iso- $\mathrm{C}_{15}$ ) & 5 & $>0.2$ & $>25$ \\
\hline phytane & 0.5 & 3 & 0.1 \\
\hline 6,10,14-trimethylpentadecan-2-one & 1.5 & 1.5 & 1 \\
\hline phytol & 43 & 20 & 2.2 \\
\hline retene $(\mathrm{XXXI})$ & approx. 0.2 & approx. 1 & approx. 0.2 \\
\hline cholest-2-ene (XIla) & 1.5 & 1 & approx. 1.5 \\
\hline 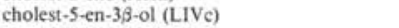 & 37 & 5.6 & 6.6 \\
\hline 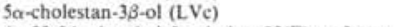 & 7.0 & 7.0 & 1 \\
\hline $\begin{array}{l}\text { 4a,23,24-trimethyl-5 } \alpha \text {-cholest-22(E)-en-3-one } \\
\text { (dinosterone, XLVc) }\end{array}$ & $<0.1$ & approx. 1 & $<0.1$ \\
\hline 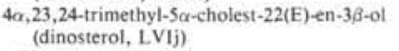 & 68 & 21 & 3.2 \\
\hline$\alpha \beta$-hopane (XVIIc) & approx. 5 & approx. 4 & approx. 1.2 \\
\hline$\beta \beta$-homohopane (XVIIIe) & approx. 5 & approx. 4 & approx, 1.2 \\
\hline hop-22(29)-ene (XVIIIf) & approx. 5 & $<0.5$ & $>10$ \\
\hline $22,29,30$-trisnorhopan-21-one (XLVI) & n.d. & 8 & 0 \\
\hline 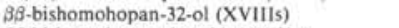 & 3.4 & 2 & 1.7 \\
\hline$\beta \beta$-bishomohopanoic acid (XVIIIu) & approx. 1.6 & $<0.2$ & $>8$ \\
\hline fern-7-ene (XXIV) & approx. 2 & approx. 1 & approx. 2 \\
\hline olean-12-en-3-one (XLVIII) & $<0.1$ & $<0.1$ & approx. 1 \\
\hline olean-12-en-3-ol ( $\beta$-amyrin, LIX) & 2.2 & 0.8 & 2.7 \\
\hline perylene (XXXIX) & $<0.1$ & 7 & $<0.02$ \\
\hline
\end{tabular}

\section{CONCLUSIONS}

The features of two Quaternary Middle America Trench sediment sections (487-2-3 and 491-1-5) shown by lipid analysis can be summarized as follows:

1) Both sections contain lipids derived from autochthonous and allochthonous sources.

2) Inputs of hydrocarbons from thermally mature sources, such as oil seeps, are evident in both samples.

3) The lipid distributions attest to the immaturity of the sediment.

4) The differences in the lipid compositions of the two samples can be interpreted as functions of their various inputs (autochthonous vs. allochthonous vs. thermally mature sources), the quality of their lipid preservation, their microbial populations, and their lithology.

5) There is considerable similarity between the lipid distributions of this sediment and those of samples from the Japan Trench.

\section{ACKNOWLEDGMENTS}

We thank the Natural Environment Research Council (GR3/2951 and supplement; GR3/3758) for support. We are grateful to Ms. Judith Best for technical assistance and to Mrs. Ann Gowar for help with the C-GC-MS facility. We also thank Drs. Jurgen Rullkötter and Phil Meyers for reviewing this manuscript.

\section{REFERENCES}

Aizenshtat, Z., Baedecker, M. J., and Kaplan, I. R., 1973. Distribution and diagenesis of organic compounds in JOIDES sediment from Gulf of Mexico and Western Atlantic. Geochim. Cosmochim. Acta, 37:1881-1898.

Albaiges, J., 1980. Identification and geochemical significance of long chain acyclic isoprenoid hydrocarbons in crude oils. In Douglas, A. G., and Maxwell, J. R. (Eds.), Advances in Organic Geochemistry 1979: Oxford (Pergamon Press), pp. 19-28.
Ballantine, J. A., Lavis, A., and Morris, R. J., 1979. Sterols of the phytoplankton-effects of illumination and growth stage. Phytochemistry, 18:1459-1466.

Ballantine, J. A., Lavis, A., Roberts, J. C., et al., 1977. Marine sterols V. Sterols of some tunicata. The occurrence of saturated ring sterols in these filter-feeding organisms. J. Exper. Mar. Biol. Ecol., 30:29-44.

Barnes, P. J., Brassell, S. C., Comet, P. A., et al., 1979. Preliminary lipid analyses of core sections 18,24 , and 30 from Hole 402A. In Montadert, L., Roberts, D. G., et al., Init. Repts. DSDP, 48: Washington (U.S. Govt. Printing Office), 965-976.

Benson, A. A., and Lee, R. F., 1975. The role of wax in oceanic food chains. Sci. Am., 232:76-86.

Boehm, P. D., and Quinn, J. G., 1978. Benthic hydrocarbons of Rhode Island Sound. Estuarine Coastal Mar. Sci., 6:471-494.

Boon, J. J., and de Leeuw, J. W., 1979. The analysis of wax esters, very long mid-chain ketones and sterol ethers isolated from Walvis Bay diatomaceous ooze. Mar. Chem., 7:117-132.

Boon, J. J., Rijpstra, W. I. C., de Lange, F., et al., 1979. The Black Sea sterol-A molecular fossil for dinoflagellate blooms. Nature, 277:125-127.

Boutry, J., and Barbier, M., 1974. La diatomie marine Chaetoceras simplex calcitans Paulsen et son environment -1 . Relations avec le milieu de culture; étude de la fraction insaponifiable des stérols libres et des acides gras. Mar. Chem., 2:217-227.

Boutry, J., and Jacques, G., 1970. Étude biochimique des planctons-III. Insaponifiables et stérols de plancton marine végétal. Bull. Soc. Chim. Biol., 52:349-352.

Brassell, S. C., 1980. The lipids of deep sea sediments; their origin and fate in the Japan Trench [Ph.D. dissert.]. University of Bristol.

Brassell, S. C., Comet, P. A., Eglinton, G., et al., 1980a. Preliminary lipid analyses of Cores 14, 18, and 28 from Deep Sea Drilling Project Hole 416A. In Lancelot, Y., Winterer, E. L., et al., Init. Repts. $D S D P, 50$ : Washington (U.S. Govt. Printing Office), 647-664.

1980b. Preliminary lipid analyses of Sections 440A-7-6, 440B-3-5, 440B-8-4, 440B-68-2, and 436-11-4; Legs 56 and 57, Deep Sea Drilling Project. In Scientific Party, Init. Repts. DSDP, 56, 57, Pt. 2: Washington (U.S. Govt. Printing Office), 13671390.

1980c. The origin and fate of lipids in the Japan Trench. In Douglas, A. G., and Maxwell, J. R. (Eds.), Advances in Organic Geochemistry, 1979: Oxford (Pergamon Press), pp. 375-392.

Brassell, S. C., and Eglinton, G., 1980. Organic geochemical studies of two samples from Holes 447A and 448 from Deep Sea Drilling Project Leg 59. In Kroenke, L., Scott, R., et al., Init. Repts. DSDP, 59: Washington (U.S. Govt. Printing Office), 647-648. ,1981. Biogeochemical significance of a novel sedimentary $\mathrm{C}_{27}$ stanol. Nature, 290:579-582.

Brassell, S. C., Eglinton, G., Maxwell, J. R., et al., 1978. Natural background of alkanes in the aquatic environment. In Hutzinger, O., van Lelyveld, L. H., and Zoeteman, B. C. J. (Eds.), Aquatic Pollutants, Transformation and Biological Effects: Oxford (Pergamon Press), pp. 69-86.

Brassell, S. C., Gowar, A. P., and Eglinton, G., 1980d. Computerised gas chromatography-mass spectromatry in analyses of sediments from the Deep Sea Drilling Project. In Douglas, A. G., and Maxwell, J. R. (Eds.), Advances in Organic Geochemistry, 1979: Oxford (Pergamon Press), pp. 421-426.

Brassell, S. C., Wardroper, A. M. K., Thomson, I. D., et al., 1981. Specific acyclic isoprenoids as biological markers of methanogenic bacteria in marine sediments: Nature, 290:693-696.

Corbet, B., Albrecht, P., and Ourisson, G., 1980. Photochemical or photomimetic fossil triterpenoids in sediments and petroleum. $J$. Am. Chem. Soc., 102:1171-1173.

Cranwell, P. A., 1973. Branched-chain and cyclopropanoid acids in a recent sediment. Chem. Geol, 11:307-313.

1980. Branched/cyclic alkanols in lacustrine sediments (Great Britain): Recognition of iso- and anteiso-branching and stereochemical analysis of homologous alkan-2-ols. Chem. Geol., 30:15-26.

Dastillung, M., and Albrecht, P., 1977. $\Delta^{2}$-Sterenes as diagenetic intermediates in sediments. Nature, 269:678-679.

Dastillung, M., Albrecht, P., and Ourisson, G., 1980a. Aliphatic and polycyclic ketones in sediments. $\mathrm{C}_{27}-\mathrm{C}_{35}$ ketones and aldehydes of the hopane series. J. Chem. Res., (S)166-167:(M)2325-2352. 
1980b. Aliphatic and polycyclic alcohols in sediments. Hydroxylated derivatives of hopane and 3-methylhopane. J. Chem. Res., (S)168-169:(M)2353-2374.

de Leeuw, J. W., Meer, F. W. v. d., Rijpstra, W. I. C., et al., 1980. On the occurrence and structural identification of long chain unsaturated ketones and hydrocarbons in sediments. In Douglas, A. G., and Maxwell, J. R. (Eds.), Advances in Organic Geochemistry, 1979: Oxford (Pergamon Press), pp. 211-217.

De Rosa, M., Gambacorta, A., Minale, L., et al., 1971. Bacterial triterpenes. J. Chem. Soc., Chem. Commun., pp. 619-620.

1972. The formation of $\omega$-cyclohexyl fatty acids from shikimate in an acidophilic thermophilic Bacillus. Biochem. J., 128:751-754.

Devon, T. K., and Scott, A. I., 1972. Handbook of Naturally-occurring Compounds, II. Terpenes: New York (Academic Press).

Edmunds, K. L. H., Brassell, S. C., and Eglinton, G., 1980. The short-term diagenetic fate of $5 \alpha$-cholestan-3 $\beta$-ol: in situ radiolabelled incubations in algal mats. In Douglas, A. G., and Maxwell, J. R. (Eds.), Advances in Organic Geochemistry 1979: Oxford (Pergamon Press), pp. 427-434.

Eglinton, G., and Hamilton, R. J., 1967. Leaf epicuticular waxes. Science, 156:1322-1335.

Eglinton, G., Hamilton, R. J., Raphael, R. A., et al., 1962. Hydrocarbon constituents of the wax coatings of plant leaves: A taxonomic survey. Nature, 193:739-742.

Ensminger, A., 1977. Evolution de composés polycycliques sédimentaires [Thèse de docteur ès sciences]. Université Louis Pasteur, Strasbourg.

Farrington, J. W., Frew, N. M., Gschwend, P. M., et al., 1977. Hydrocarbons in cores of northwestern Atlantic coastal and continental margin sediments. Estuarine Coastal Mar. Sci., 5:793-808.

Gagosian, R. B., and Farrington, J. W., 1978. Sterenes in surface sediments from the southwest African shelf and slope. Geochim. Cosmochim. Acta, 42:1091-1101.

Gagosian, R. B., Lee, C., and Heinzer, F., 1979. Processes controlling the stanol/stenol ratio in Black Sea seawater and sediments. Nature, 280:574-576.

Gagosian, R. B., and Smith, S. O., 1979. Steroid ketones in surface sediments from the south-west African shelf. Nature, 277: 287-289.

Gagosian, R. B., Smith, S. O., Lee, C., et al., 1980. Steroid transformations in Recent marine sediments. In Douglas, A. G., and Maxwell, J. R. (Eds.), Advances in Organic Geochemistry 1979: Oxford (Pergamon Press), pp. 407-419.

Gaskell, S. J., and Eglinton, G., 1975. Rapid hydrogenation of sterols in a contemporary lacustrine sediment. Nature, 254:209-211. 1976. Sterols of a contemporary lacustrine sediment. Geochim. Cosmochim. Acta, 40:1221-1228.

Goad, L. J., Rubinstein, I., and Smith, A. G., 1972. The sterols of echinoderms. Proc. R. Soc. London Ser. B., 180:223-246.

Greiner, A. Ch., Spyckerelle, C., Albrecht, P., et al., 1977. Aromatic hydrocarbons from geological sources V: Mono- and diaromatic hopane derivatives. J. Chem. Res., (S)334:(M)3829-3871.

Holzer, G., Oró, J., and Tornabene, T. G., 1979. Gas chromatographic/mass spectrometric analysis of neutral lipids from methanogenic and thermoacidophilic bacteria. J. Chromatog., 186: 795-809.

Howard, D. L., 1980. Polycyclic triterpenes of the anaerobic photosynthetic bacterium Rhodomicrobium vannielli [Ph.D. dissert.]. University of California, Los Angeles.

Huang, W-y., and Meinschein, W. G., 1976. Sterols as source indicators of organic material in sediments. Geochim. Cosmochim. Acta, 40:323-330.

Ikan, R., Baedecker, M. J., and Kaplan, I. R., 1975. Thermal alteration experiments on organic matter in recent marine sediment-II. Isoprenoids. Geochim. Cosmochim. Acta, 39:187-194.

Ishiwatari, R., and Fukushima, K., 1979. Generation of unsaturated and aromatic hydrocarbons by thermal alteration of young kerogen. Geochim. Cosmochim. Acta, 43:1343-1349.

Johns, R. B., Belsky, T., McCarthy, E. D., et al., 1966. The organic geochemistry of ancient sediments, Part II. Geochim. Cosmochim. Acta, 30:1191-1222.

Johnson, R. W., and Calder, J. A., 1973. Early diagenesis of fatty acids and hydrocarbons in a salt marsh environment. Geochim. Cosmochim. Acta, 37:1943-1955.
Kanazawa, A., Teshima, S., and Ando, T., 1977. Sterols of coelenterates. Comp. Biochem. Physiol., 57B:317-323.

Kimble, B. J., 1972. The geochemistry of triterpenoid hydrocarbons [Ph.D. dissert.]. University of Bristol.

Kimble, B. J., Maxwell, J. R., Philp, R. P., et al., 1974. Tri- and tetraterpenoid hydrocarbons in the Messel Oil Shale. Geochim. Cosmochim. Acta, 38:1165-1181.

Laflamme, R. E., and Hites, R. A., 1978. The global distribution of polycyclic aromatic hydrocarbons in recent sediments. Geochim. Cosmochim. Acta, 42:289-303.

1979. Tetra- and pentacyclic, naturally-occurring, aromatic hydrocarbons in recent sediments. Geochim. Cosmochim. Acta, 43:1687-1691.

Lee, C., Farrington, J. W., and Gagosian, R. B., 1979. Sterol geochemistry of sediments from the Western North Atlantic Ocean and adjacent coastal areas. Geochim. Cosmochim. Acta, 43: $35-46$.

Lee, C., Gagosian, R. B., and Farrington, J. W., 1977. Sterol diagenesis in recent sediments from Buzzards Bay, Massachusetts. Geochim. Cosmochim. Acta, 41:985-992.

Lee, R. F., Nevenzel, J. C., and Pfaffenhofer, G. A., 1971. Importance of wax esters and other lipids in the marine food chain: Phytoplankton and copepods. Mar. Biol., 9:99-108.

McEvoy, J., Eglinton, G., and Maxwell, J. R., in press. Preliminary lipid analyses of sediments from Sections 467-3-3 and 467-97-2. In Haq, B. U., Yeats, R. S., et al., Init. Repts. DSDP, 63: Washington (U.S. Govt. Printing Office), 763-774.

Mackenzie, A. S., Patience, R. L., Maxwell, J. R., et al., 1980. Molecular parameters of maturation in the Toarcian shales, Paris Basin, France I. Changes in the configurations of acyclic isoprenoid alkanes, steranes and triterpanes. Geochim. Cosmochim. Acta, 44:1709-1721.

Matsuda, H., and Koyama, T., 1977. Early diagenesis of fatty acids in lacustrine sediments-I. Identification and distribution of fatty acids in recent sediments from a freshwater lake. Geochim. Cosmochim. Acta, 41:777-783.

Maxwell, J. R., Pillinger, C. T., and Eglinton, G., 1971. Organic geochemistry. Q. Rev., 25:571-628.

Moldowan, J. M. and Seifert, W. K., 1979. Head-to-head linked isoprenoid hydrocarbons in petroleum. Science, 204:169-171.

Nes, W. R., and McKean, M. L., 1977. Biochemistry of Steroids and Other Isopentenoids: Baltimore (University Park Press).

Nevenzel, J. C., 1970. Occurrence, function and biosynthesis of wax esters in marine organisms. Lipids, 5:308-319.

Nishimura, M., and Koyama, T., 1976. Stenols and stanols in lake sediments and diatoms. Chem. Geol., 17:229-239.

, 1977. The occurrence of stanols in various organisms and the behavior of sterols in contemporary sediments. Geochim. Cosmochim. Acta, 41:379-385.

Orcutt, D. M., and Patterson, G. W., 1975. Sterol, fatty acid and elemental composition of diatoms grown in chemically defined media. Comp. Biochem. Physiol., 50B:579-583.

Ourisson, G., Albrecht, P., and Rohmer, M., 1979. The hopanoids. Palaeochemistry and biochemistry of a group of natural products. Pure Appl. Chem., 51:709-729.

Parker, P. L., Van Baalen, C., and Maurer, L., 1967. Fatty acids in eleven species of blue green algae: geochemical significance. Science, 155:707-708.

Patience, R. L., Rowland, S. J., and Maxwell, J. R., 1978. The effect of maturation on the configuration of pristane in sediments and petroleum. Geochim. Cosmochim. Acta, 42:1871-1875.

Prahl, F. G., Bennett, J. T., and Carpenter, R., 1980. The early diagenesis of aliphatic hydrocarbons and organic matter in sedimentary particulates from Dabob Bay, Washington. Geochim. Cosmochim. Acta, 44:1967-1976.

Rohmer, M., 1975. Triterpénoides de procaryotes [Thèse de doctorat ès Sciences]. Université Louis Pasteur, Strasbourg.

Rohmer, M., Dastillung, M., and Ourisson, G., 1980. Hopanoids from $C_{30}$ to $C_{35}$ in recent muds. Naturwissenschaften, 67:456-458.

Rubinstein, I., Sieskind, O., and Albrecht, P., 1975. Rearranged sterenes in a shale: Occurrence and simulated formation. J. Chem. Soc. Perkin Trans. I, 1833-1835.

Rubinstein, I., and Strausz., O. P., 1979. Geochemistry of the thiourea adduct fraction from an Alberta petroleum. Geochim. Cosmochim. Acta, 43:1387-1392. 
Rullkötter, J., von der Dick, H., and Welte, D. H., in press. Organic petrography and extractable hydrocarbons of sediments from the Gulf of California, Deep Sea Drilling Project Leg 64. In Curray, J. R., Moore, D. G., et al., Init. Repts. DSDP, 64: Washington (U.S. Govt. Printing Office).

Schaeffle, J., Ludwig, B., Albrecht, P., et al., 1978. Aromatic hydrocarbons from geological sources VI: New aromatic steroid derivatives in sediments and crude oils. Tetrahedron Lett., pp. 4163-4166.

Seifert, W. K., and Moldowan, J. M., 1979. The effect of biodegradation on steranes and terpanes in crude oils. Geochim. Cosmochim. Acta, 43:222-236.

Shimizu, Y., Alam, M., and Kobayashi, A., 1976. Dinosterol, the major sterol with a unique side chain in the toxic dinoflagellate, Gonyaulex tamarensis. J. Am. Chem. Soc., 98:1059-1060.

Simoneit, B, R. T., 1977. Diterpenoid compounds and other lipids in deep-sea sediments and their geochemical significance. Geochim. Cosmochim. Acta, 41:463-476.

1978. The organic chemistry of marine sediments. In Riley, J. P., and Chester, R. (Eds.), Chemical Oceanography, 7: London (Academic Press), 233-311.

Speers, G. C., and Whitehead, E. V., 1969. Crude petroleum. In Eglinton, G., and Murphy, M. T. J. (Eds.), Organic Geochemistry, Methods and Results: Berlin (Springer-Verlag), pp. 638-675.

Spyckerelle, C., 1975. Constituents aromatiques de sédiments [Thèse de docteur ès sciences]. Université Louis Pasteur, Strasbourg.

Spyckerelle, C., Greiner, A. Ch., Albrecht, P., et al., 1977a. Aromatic hydrocarbons from geological sources-III. A tetrahydrochrysene derived from triterpenes in Recent and old sediments, 3,3,7-trimethyl-1,2,3,4-tetrahydrochrysene. J. Chem. Res., (S)330-331:(M)3746-3777.

1977b. Aromatic hydrocarbons from geological sourcesIV. An octahydrochrysene derived from triterpenes in Recent and old sediments, 3,3,7,12a-tetramethyl-1,2,3,4,4a,11,12,12a-octahydrochrysene. J. Chem. Res., (S)332-333:(M)3801-3828.

Thomson, I. D., Brassell, S. C., Comet, P. A., et al., in press a. Preliminary lipid analyses of Cores 49, 54 and 59 from Hole 462. In Larson, R. L., Schlanger, S., et al., Init. Repts. DSDP, 61: Washington (U.S. Govt. Printing Office), 613-618.

Thomson, I. D., Brassell, S. C., Eglinton, G., et al., in press b. Preliminary lipid analyses of Section 481-2-2. In Curray, J. R., Moore, D. G., et al., Init. Repts. DSDP, 64: Washington (U.S. Govt. Printing Office).

Thompson, S., and Eglinton, G., 1978. The fractionation of a Recent sediment for organic geochemical analysis. Geochim. Cosmochim. Acta, 42:199-207.

Tissier, M. J., and Dastillung, M., 1978. Inventaire et dynamique des lipides à l'interface eau de mar-sédiment V. Hydrocarbures polyaromatiques des sédiments, de l'eau de mer et de l'eau intersti- tielle. Géochimie Organique des Sédiments Marins Profonds, Orgon II: Atlantique-N.E. Brésil: Paris (Editions du C.N.R.S.), pp. 275-283.

Tissot, B. P., and Welte, D. H., 1978. Petroleum Formation and Occurrence: Berlin (Springer-Verlag).

Tornabene, T., G., Langworthy, T. A., Holzer, G., et al., 1979. Squalenes, phytanes and other isoprenoids as major neutral lipids of methanogenic and thermoacidophilic "Archaebacteria." J. Mol. Evol., 13:73-83.

Urbach, G., and Stark, W., 1975. The C-20 hydrocarbons of butterfat. J. Agric. Food Chem., 23:20-24.

Volkman, J. K., Eglinton, G., Corner, E. D. S., et al., 1980a. Novel unsaturated straight chain $\mathrm{C}_{37}-\mathrm{C}_{39}$ methyl and ethyl ketones in marine sediments and a coccolithophore Emiliania huxleyi. In Douglas, A. G., and Maxwell, J. R. (Eds.), Advances in Organic Geochemistry 1979: Oxford (Pergamon Press), pp. 219-228.

$1980 \mathrm{~b}$. Long-chain alkenes and alkenones in the marine coccolithophorid Emiliania huxleyi. Phytochemistry, 19:26192622.

$1980 \mathrm{c}$. Sterols and fatty acids of the marine diatom Biddulphia sinensis. Phytochemistry, 19:1809-1813.

Volkman, J. K., and Johns, R. B., 1977. The geochemical significance of positional isomers of unsaturated acids from an intertidal zone sediment. Nature, 267:693-694.

Wakeman, S. G., Farrington, J. W., Gagosian, R. B., et al., 1980c. Organic matter fluxes from sediment traps in the equatorial Atlantic Ocean. Nature, 286:798-800.

Wakeham, S. G., Schaffner, C., Giger, W., et al., 1979. Perylene in sediments from the Namibian Shelf. Geochim. Cosmochim. Acta, 43:1141-1144.

1980a. Polycyclic aromatic hydrocarbons in Recent lake sediments-II. Compounds derived from biogenic precursors during early diagenesis. Geochim. Cosmochim. Acta, 44:415-429. ,1980b. Diagenetic polycyclic aromatic hydrocarbons in Recent sediments: Structural information obtained by high performance liquid chromatography. In Douglas, A. G., and Maxwell, J. R. (Eds.), Advances in Organic Geochemistry 1979: Oxford (Pergamon Press), pp. 353-363.

Wardroper, A. M. K., 1979. Aspects of the geochemistry of polycyclic isoprenoids [Ph.D. dissert.]. University of Bristol.

Wardroper, A.M.K., Maxwell, J. R., and Morris, R. J., 1978. Sterols of a diatomaceous ooze with Walvis Bay. Steroids, 32:203-221.

Withers, N.W., Kokke, W.C.M.C., Rohmer, M., et al.,1979. Isolation of sterols with cyclopropyl-containing side chains from the cultured marine alga Peridinium fociaceum. Tetrahedron Lett., 3605-3608.

Withers, N. W., Tuttle, R. C., Holz, G. G., et al., 1978. Dehydrodinosterol, dinosterone and related sterols of a non-photosynthetic dinoflagellate, Crypthecodinium cohnii. Phytochemistry, 17:19871989. 
A

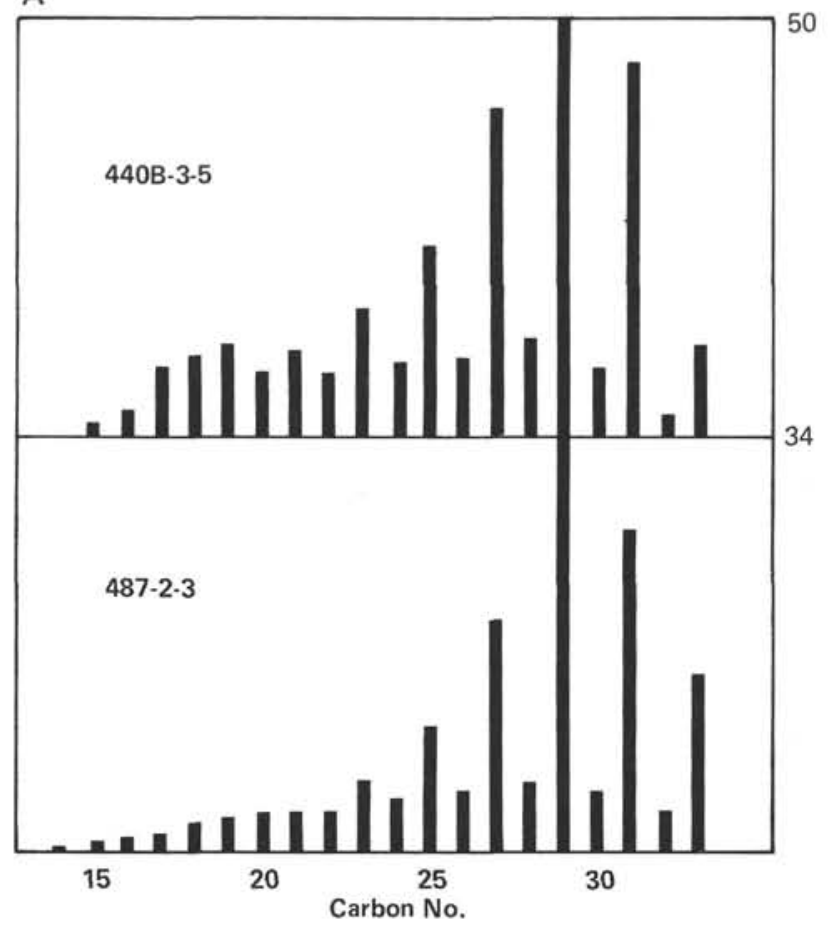

B

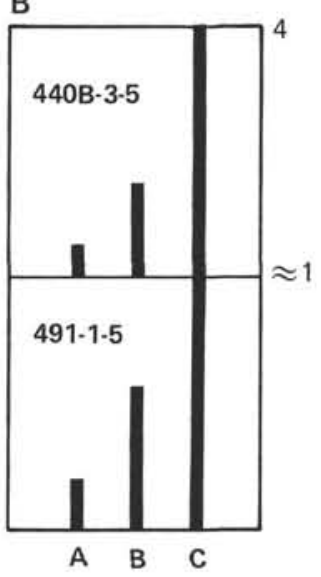

C

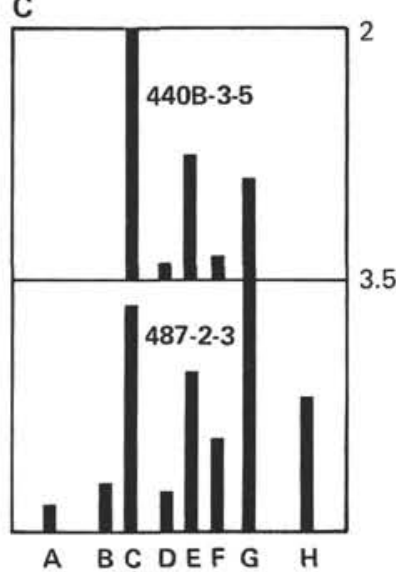

D

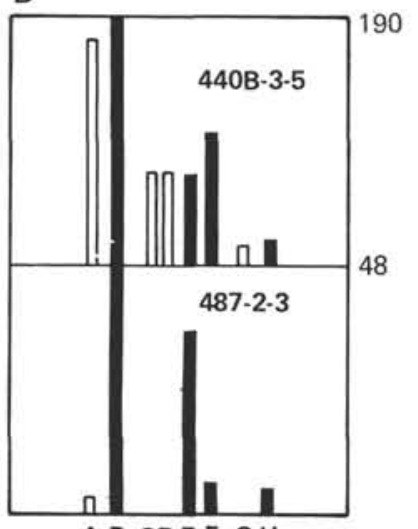

A B CDEF GH
E

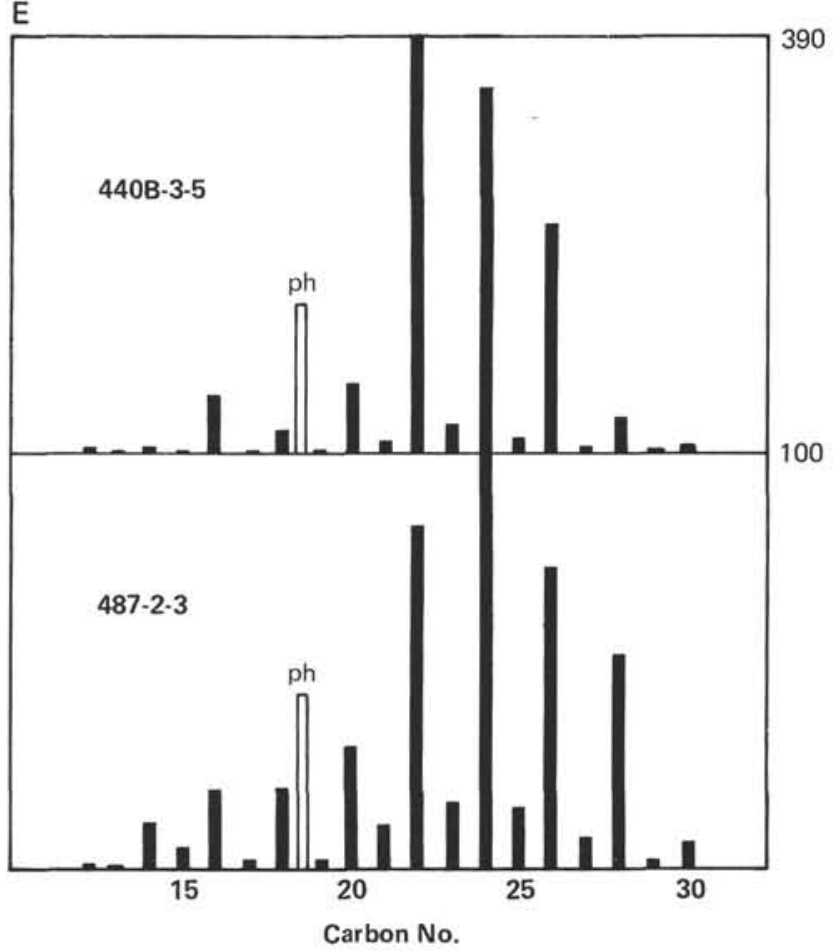

Figure 6. Comparison of lipid distributions of Quaternary Middle America and Japan Trench sediments. A. Concentrations (ng/g dry sediment) of $n$-alkanes in Sections 440B-3-5 and 487-2-3. B. Concentrations (ng/g dry sediment) of fernenes in Sections 440B-3-5 and 491-1-5. $\left(\mathrm{A}=\right.$ fern-8-ene (XX); $\mathrm{B}=$ fern-9(11)-ene (XXII); $\mathrm{C}=$ fern-7-ene (XXIV).) C. Concentrations (ng/g dry sediment) of $\mathrm{C}_{24}$ tetracyclic alkanes/alkenes, assigned as ring A degraded triterpenoids in Sections 440B-3-5 and 487-2-3. Formulae as in Figure 2. D. Concentrations (ng/g dry sediment) of alkadienones (solid bar) and alkatrienones (open bars) in Sections 440B-3-5 and 487-2-3. (A $=$ heptatriaconta-8,15,22-trien-2-one (XLa); $\mathrm{B}=$ heptatriaconta-15,22-dien-2-one (XLIa); C = octatriaconta-9,16,23-trien-3-one $(\mathrm{XLb}) ; \mathrm{D}=$ octatriaconta-9,16,23-trien-2-one (XLc); $\mathrm{E}=$ octatriaconta-16,23-dien-3-one (XLIb); $\mathrm{F}=$ octatriaconta-16,23-dien-2one (XLIc); $\mathrm{G}$ = nonatriaconta-10,17,24-trien-3-one (XLd); $\mathrm{H}$ = nonatriaconta-17,24-dien-3-one (XLId). The peak lettering differs from that of Fig. 3. E. Concentrations (ng/g dry sediment) of $n$-alkanols and phytol in Sections $440 \mathrm{~B}-3-5$ and $487-2-3$. (ph $=$ phytol [open bar].) 
Table 12. Qualitative differences and similarities between selected lipid distributions of Japan and Middle America Trench sediments.

\begin{tabular}{|c|c|c|}
\hline $\begin{array}{l}\text { Lipid Structural } \\
\text { Class }\end{array}$ & $\begin{array}{l}\text { Comparison between Middle America (Leg 66) and } \\
\text { Japan (Legs 56/57) Trench Sediments }{ }^{\mathrm{a}} \text { a }\end{array}$ & Comments on Differences \\
\hline straight-chain & $\begin{array}{l}\text { distributions of alkanes, alkan-2-ones, alkanols, } \\
\text { alkanoic acids, alkenols and alkenoic acids } \\
\text { generally similar (Fig. 6); alkadienone/alkatrienone } \\
\text { ratios much higher in Leg } 66 \text { (Fig. 6) }\end{array}$ & $\begin{array}{l}\text { alkenones may differ because of environmental conditions } \\
\text { or diagenetic effects }\end{array}$ \\
\hline branched-chain & $\begin{array}{l}\text { distributions of alkanols and alkanoic acids } \\
\text { similar; range of alkanes greater in Leg } 66\end{array}$ & $\begin{array}{l}\text { alkanes of Legs } 56 / 57 \text { are direct biological inputs; those } \\
\text { of Leg } 66 \text { come from a thermally mature source }\end{array}$ \\
\hline acyclic isoprenoid & $\begin{array}{l}\text { distributions of alkanes, alkanones, and alcohols } \\
\text { similar; phytenes more abundant in Legs } 56 / 57\end{array}$ & $\begin{array}{l}\text { phytol diagenesis may be more advanced in Legs } 56 / 57 \\
\text { or phytenes may reflect lipid inputs from methanogens }\end{array}$ \\
\hline cyclic diterpenoid & $\begin{array}{l}\text { distributions of acids similar; range of alkanes and } \\
\text { aromatic diterpenoids greater in Legs } 56 / 57\end{array}$ & $\begin{array}{l}\text { inputs may be similar, but the extent of diagenetic } \\
\text { alteration varies }\end{array}$ \\
\hline steroids & $\begin{array}{l}\text { range of sterols and sterenes greater in Legs } 56 / 57 \text {, } \\
\text { although relative abundance of common } \\
\text { components are similar; diasterenes only present } \\
\text { in Legs } 56 / 57 \text {; sterane distributions differ }\end{array}$ & $\begin{array}{l}\text { a greater diversity of marine organisms (e.g., diatoms) } \\
\text { may contribute sterols and thence their diagenetic } \\
\text { products to Legs } 56 / 57 \text {, which are also diagenetically } \\
\text { more mature, except in comparison to the thermally } \\
\text { mature steranes of Leg } 66\end{array}$ \\
\hline triterpenoids-hopanoid & $\begin{array}{l}\text { alkane, alkene, alkanol, and alkanoic acid } \\
\text { distributions generally similar; range of alkanones } \\
\text { greater in Legs } 56 / 57\end{array}$ & minor differences reflect diagenetic discrepancies \\
\hline nonhopanoid & $\begin{array}{l}\text { fernene distributions similar (Fig. 6), as are ranges } \\
\text { of higher plant triterpenones, triterpenols, and } \\
\text { their tetracyclic alkane, alkene, and aromatic } \\
\text { derivatives (Fig. 6) }\end{array}$ & $\begin{array}{l}\text { minor differences reflect variations in sediment inputs } \\
\text { and/or diagenetic processes }\end{array}$ \\
\hline
\end{tabular}


Compound Structures

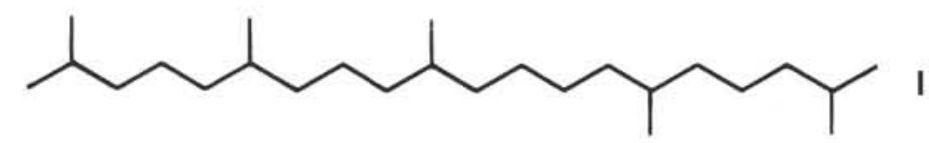<smiles>CC(C)CCCC(C)CCCC(C)CCCCC(C)CCCC(C)CCCC(C)C</smiles><smiles>CCC(C)CCCC(C)CCCC(C)CCCC(C)CCCC(C)C</smiles><smiles>CC(C)CCCC(C)CCCC(C)CCCC(C)CCC(C)CCCCC(C)CCCC(C)CCCC(C)CCN</smiles><smiles>CC(C)CCCC(C)CCCC(C)CCCC(C)CCCCC(C)CCCC(C)CCCC(C)CCCC(C)CCCC(C)C</smiles>
疗<smiles>CC(C)C1CCC2C(CCC3C(C)CCC[C@]32C)C1</smiles><smiles>[R]CC1CCC2CCCCC2(C)C1CC[C@]12CCC([R])C1CCC2[R]</smiles><smiles>[X]C1CCC2(C)C1CCC1C3CCCCC3(C)CCC12</smiles><smiles>[R]C1CCC2C3CCC4CCCCC4(C)C3CCC12C</smiles><smiles>[R]C1CCC2C3CCC4CC=CC[C@]4(C)C3CC[C@]12C</smiles><smiles>[R]C1CCC2C3CC=C4C=CCC[C@]4(C)C3CC[C@]12C</smiles><smiles>[R]C1CCC2C1CCC1(C)C(CC(C)C)CCC1C1c3ccccc3CCC21</smiles>

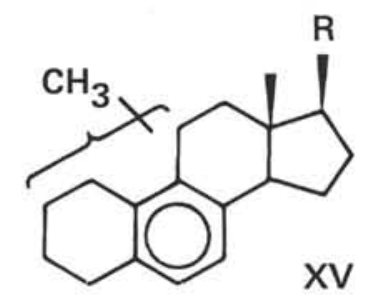

$\mathrm{R}=$<smiles>CC(C)CCCC(C)C</smiles>

a<smiles>CC(C)=CCCC(C)C</smiles>

b<smiles>CC(C)CCC(C)C(C)C</smiles>

c<smiles>C=C(CCC(C)C)C(C)C</smiles><smiles>CCC(C=CC(C)C)C(C)C</smiles><smiles>CC(C)CC(C)C(C)C(C)C</smiles><smiles>CCC(CCC(C)C)C(C)C</smiles><smiles>C/C=C(/CCC(C)C)C(C)C</smiles> 

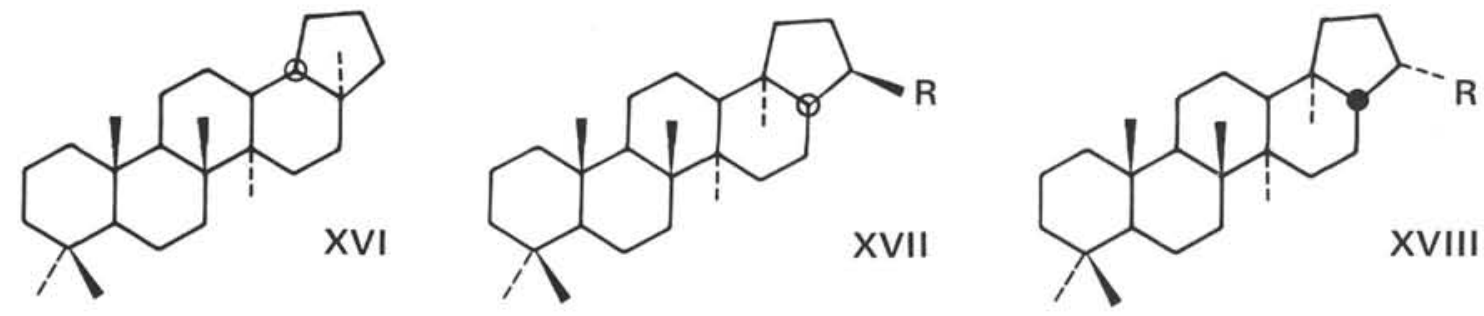

$R=$

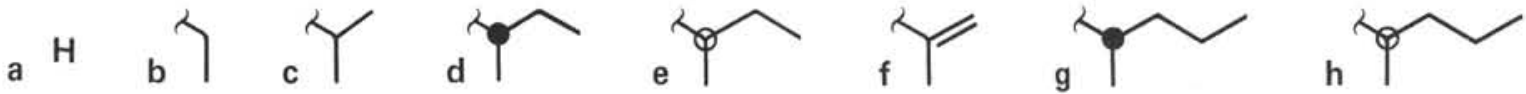

PO

POC

$\overbrace{\mathrm{OH}}$<smiles>[X]C(C)CC(O)C(O)C(O)C(O)CO</smiles><smiles>[Y][X]</smiles>
$\mathrm{XIX}$<smiles>CC(C)C(C)C1(C)CCC2(C)C3CCC4C(C)(C)CCC[C@]4(C)C3=CC[C@]2(C)C1C</smiles>

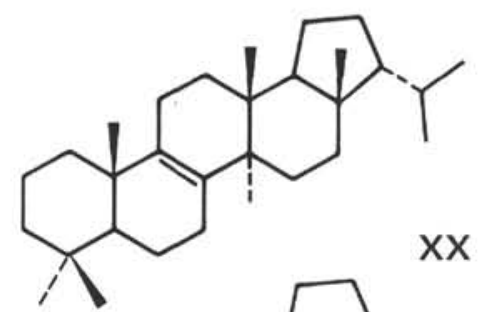<smiles>CC(C)C1CCC2C3=CCC4C(C)(C)CCC[C@]4(C)[C@@H]3CC[C@]21C</smiles><smiles>[Y4]O[M]</smiles><smiles>[Y4][X]</smiles>

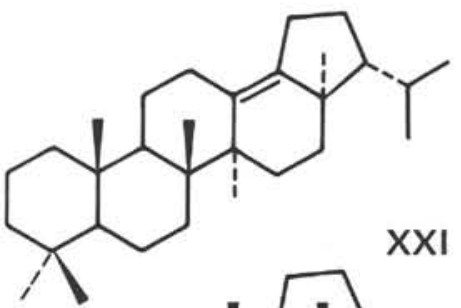<smiles>CCCC(C)(C)C</smiles>

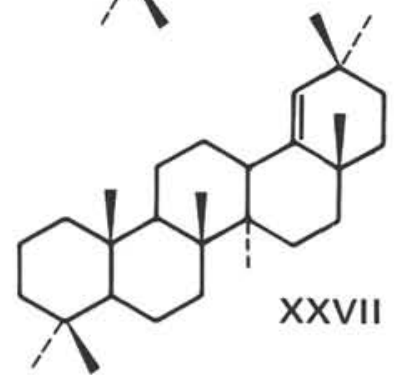



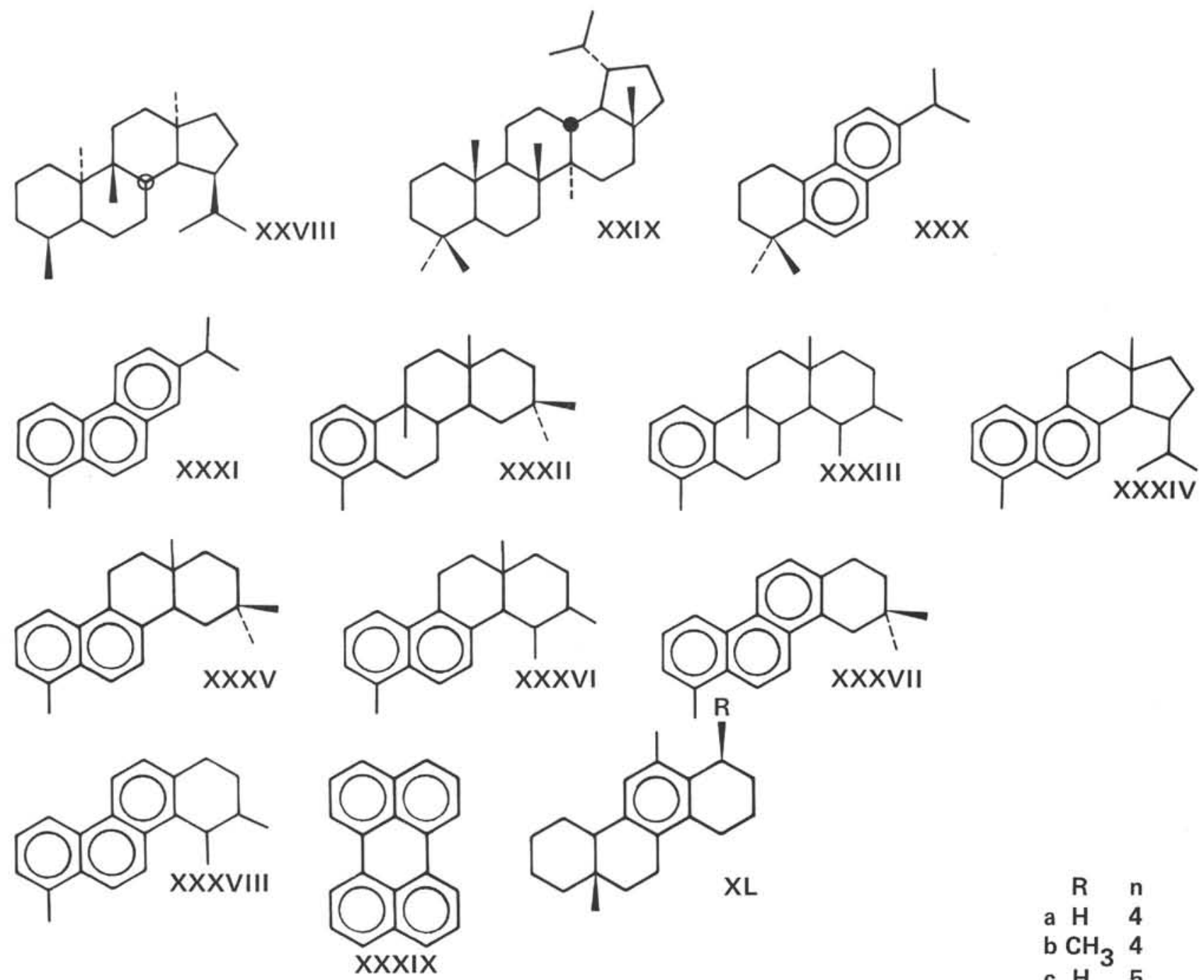

$\prod_{0}$

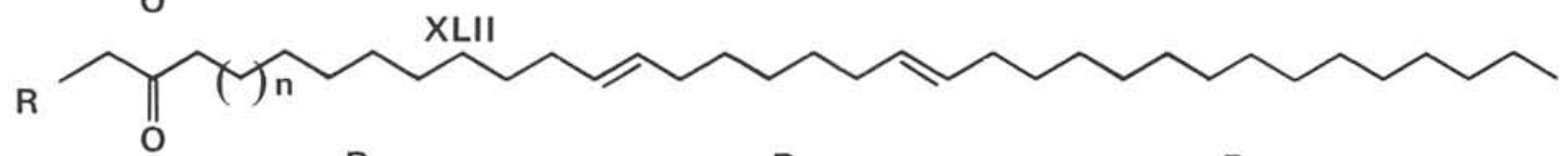

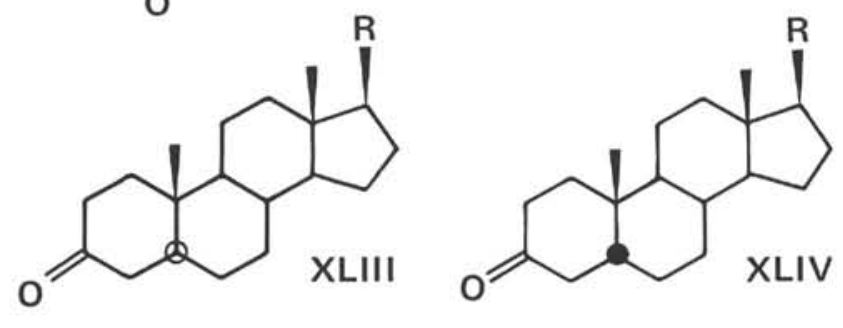<smiles>[R]C1CCC2C3CCC(C)C3(C)CCC12CCC(=O)C(C)C</smiles>

$$
\begin{aligned}
& \begin{array}{rr}
\mathrm{R} & \mathrm{n} \\
\mathrm{H} & 4
\end{array} \\
& \text { b } \mathrm{CH}_{3} 4 \\
& \text { c } \mathrm{H}^{3} 5 \\
& \text { d } \mathrm{CH}_{3} 5
\end{aligned}
$$<smiles>[B]C(C)CCC(CC)C(C)C</smiles> 


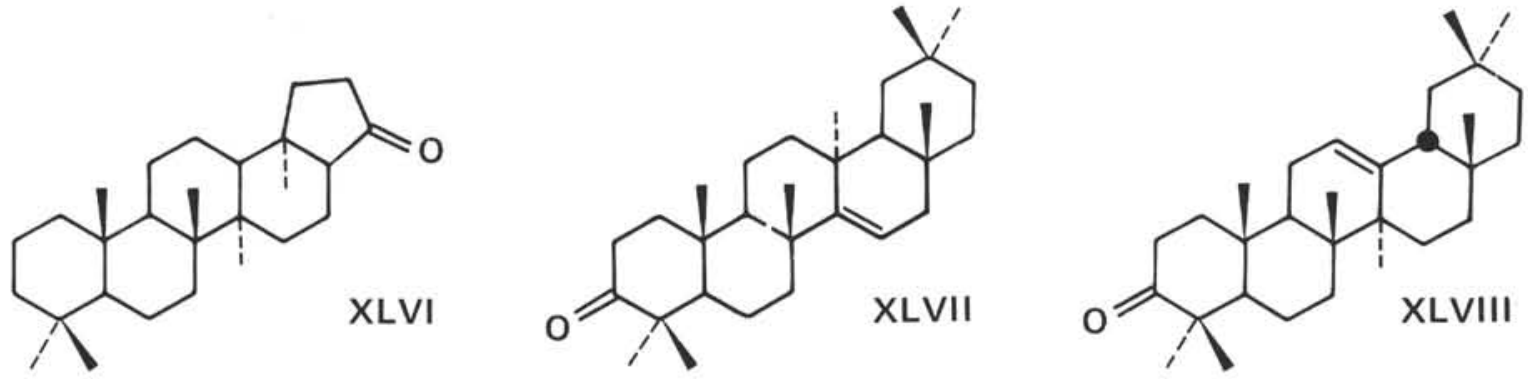<smiles>[R4][X]</smiles><smiles>CC(=O)C1CCC2(C)C1CCC1(C)C2CCC2C(C)(C)CCC[C@@]21C</smiles><smiles>CC(C)C1CCC2(C)C1CCC1(C)C2CCC2C1(C)CCC1C(C)(C)C(=O)CC[C@]12C</smiles><smiles>CC1(C)CCC23CC[C@@]4(C)C5CCC(=O)C(C)(C)C5=CCC4C4(C)CCC2(C)C(C1)C43</smiles><smiles>C[C@H]1C(=O)CCC2[C@@]3(C)CCC4(C)C5CC(C)(C)CC[C@]5(C)CC[C@]4(C)C3CC[C@]21C</smiles><smiles>[R][C@@H]1CCC2C3CCC4=C[C@@H](O)CC[C@]4(C)C3CC[C@@]21C</smiles><smiles>[R]C1CC2C1CC1C3CCC4CC(O)CC[C@]4(C)C3CC[C@]21C</smiles><smiles></smiles>
LVI LVII<smiles>[R]=[Pt]C(C)/C=C/C(C)C</smiles><smiles>C=C(CCC(C)CC(C)C)C(C)C</smiles><smiles>[Y]C(C)/C=C\C(CC)C(C)C</smiles> 
S. C. BRASSELL, G. EGLINTON, J. R. MAXWELL<smiles>[2H]CC(C)C(C)C(C)CC(C)C</smiles><smiles>CC(C)C(C)CC(C)C(C)CCl</smiles><smiles>CC(C)C(C)C1CC1C(C)C</smiles><smiles>CC1(C)CC[C@]2(C)CC=C3[C@@]4(C)CCC5C(C)(C)C(O)CC[C@]5(C)C4CC[C@]3(C)C2C1</smiles>

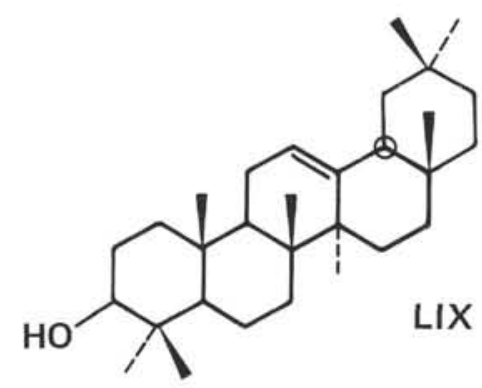

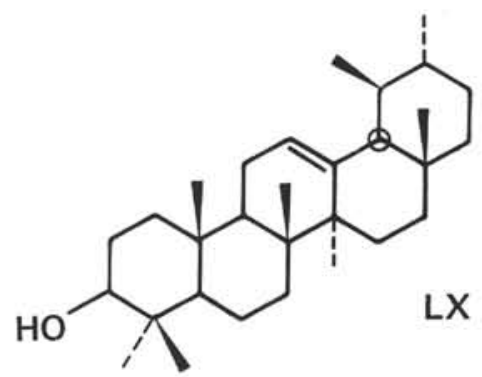

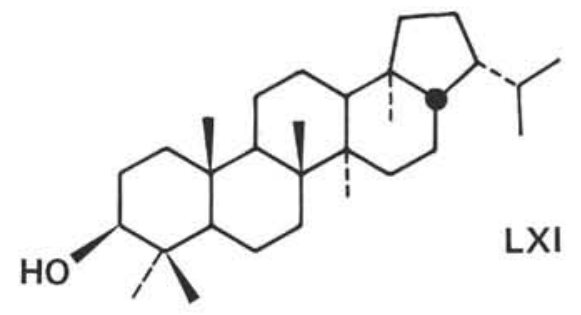<smiles>CC(C)C1CCC2C1CCC1(C)C2CCC2[C@]3(C)CCCC(C)(C)C3C(O)C[C@]21C</smiles><smiles>CC(C)c1ccc2c(c1)CCC1[C@@](C)(C(=O)O)CCC[C@@]21C</smiles><smiles>O=C(O)CCC1CCCCC1</smiles><smiles>CC(C)CCC[C@@H](C)[C@H]1CCC2C3CC[C@]4(C)CC[C@@H](O)CC4C3CC[C@]21C</smiles><smiles>CCC(C)CC[C@H](C)[C@H]1CCC2C3CCC4C[C@@H](O)CC[C@]4(C)C3CC[C@]21C</smiles><smiles>CC(C)CCC[C@@H](C)[C@H]1CCC2C3CC[C@H]4CC(O)CC[C@]4(C)C3CC[C@]21C</smiles><smiles>[X][X]C1CC[C@H]([R])[C@@]12CC[C@@H]1C3=CC=C4C[C@@H](O)CC[C@]4(C)C3CC[C@]12C</smiles> 